\title{
Managerial Ability, Earnings Quality and ISIS: Evidence from Iraq
}

\begin{abstract}
Purpose - This study investigates the association between managerial ability and earnings quality in firms listed on the Iraq Stock Exchange and how the emergence of the Islamic State of Iraq and Syria (ISIS) influences the association.

Design/methodology/approach - This study uses a sample of firms listed on the Iraq Stock Exchange over the period 2012-2018. Managerial ability is quantified using data envelopment analysis, and earnings quality is measured by earnings restatement, earnings persistence, accruals quality, and earnings response coefficient. Panel regression analysis is used to examine the research hypotheses.
\end{abstract}

Findings - The findings indicate that managerial ability positively affects earnings quality of Iraqi firms, and that ISIS weakens the relationship between managerial ability and earnings quality. These findings are robust to the alternative measures of managerial ability, as well as to various approaches used to address endogeneity including propensity-score matching and a difference-in-differences analysis.

Originality/value - This study provides insight into the impact of managerial ability on earnings quality in an under-studied emerging market. Furthermore, this study broadens the existing literature about the financial consequences of a modern terrorist group, ISIS.

Keywords: managerial ability, earnings quality, emerging markets, Iraq Stock Exchange, ISIS 


\section{Introduction}

The managerial heterogeneity literature (e.g., Demerjian et al. 2013; Yung and Chen 2018; Baik et al., 2020; Chen et al., 2020a; Choo et al., 2020; Doukas and Zhang, 2020; Francis et al., 2020; Hesarzadeh, 2020; Luu et al., 2020; Oskouei and Sureshjani, 2020; Yung and Nguyen, 2020) indicates that managerial ability — defined as higher power in the generation of sales revenue for a given set of resources the firm owns (Demerjian et al., 2012) - is an important factor that affects tax avoidance, corporate investment, cost of debt, corporate innovative success, executive compensation and firm performance. ${ }^{1}$ Particularly, in the context of financial reporting, prior studies (e.g., Demerjian et al., 2013; 2017; Huang and Sun, 2017) show that managerial ability significantly affects earnings quality. However, the literature provides mixed evidence on how managerial ability influences earnings quality. On the one hand, higher managerial ability reflects more managerial knowledge of the business and its operating environment which leads to better judgments, estimates and monitoring, and hence, higher earnings quality (e.g., Demerjian et al., 2013; Wells, 2020). On the other hand, more able managers may increase their payoffs through opaque corporate reporting and poor earnings quality (e.g., Demerjian et al., 2017). While in developed markets there is empirical evidence supporting the positive impact of managerial ability on earnings quality, there is scarce evidence in the case of emerging markets, where their unique complexities can lead to different results.

One possible reason for the aforementioned discrepancy is outlined in the literature, which suggests that the impact of managerial ability on diverse variables may be influenced by uncertainty (e.g., Rosen, 1981; Gabaix and Landier, 2008; Bamber et al., 2010; Hribar et

\footnotetext{
${ }^{1}$ Following the literature (e.g., Demerjian et al., 2012; Choi et al., 2015; Baik et al., 2020; Chen et al., 2020a; Doukas and Zhang, 2020; Francis et al., 2020; Luu et al., 2020; Oskouei and Sureshjani, 2020; Yung and Nguyen, 2020), this paper defines managerial ability based on managerial efficiency, relative to their industry peers, in transforming corporate resources to revenues. Assessing managerial ability based on managerial efficiency is intuitively appealing as it is in line with the overarching goal of profit-maximizing firms (e.g., Demerjian et al., 2012; Doukas and Zhang, 2020).
} 
al., 2017; Chen et al., 2020a). Particularly, prior studies (e.g., Kim et al., 2015; Boone et al., 2018; Chen, 2019) document that the effect of management varies with the degree of uncertainty; the higher (lower) the uncertainty, the more (less) judgment is needed for accounting choices, and hence a stronger (weaker) impact of managerial ability is thus expected. To empirically investigate how uncertainty influences the relationship between managerial ability and earnings quality, we focus on the influence of terrorist activities as an exogenous force which increases uncertainty (e.g., Czinkota et al., 2010; Chen, 2019).

This study examines the impact of managerial ability on earnings quality in the context of an under-studied emerging market, the Iraq Stock Exchange. The Iraqi market provides a unique setting as it has had to operate in an environment along with a modern terrorist group, Islamic State of Iraq and Syria (ISIS). ISIS gained global prominence in late 2014 when it drove the Government of Iraq forces out of important cities in its Western Iraqi offensive. ISIS has been recognized as a terrorist organization by most countries around the world. Traditionally, terrorism was largely viewed as being a phenomenon to be best understood through legal and security lenses (Simons, 2018). However, little is known about the economic consequences of terroristic activities in general and ISIS activities in particular (e.g., Githing'u et al., 2020). This study investigates the impact of ISIS in the context of business to see how earnings quality of Iraqi firms is affected.

Using a sample of 245 firm-years observations from the Iraq Stock Exchange, the findings suggest that there is a positive link between managerial ability and earnings quality. Furthermore, consistent with theoretical arguments suggesting that the uncertainty caused by ISIS can affect managerial estimation and judgment (e.g., El Ghoul et al., 2020), this paper finds that the presences of ISIS and geographical proximity to ISIS negatively affect the association between managerial ability and earnings quality. 
This study contributes to the empirical literature on the association between managerial ability and earnings quality by investigating an under-studied emerging market setting. More importantly, it sheds light on how the emergence of ISIS may influence the aforementioned association. Thus, this study contributes to positive accounting theory, where the central theme is accounting choices by managers, and provides evidence on how terrorism influences earnings quality. While terrorism is generally studied through legal and security frameworks (Simons, 2018), this study adds to a growing body of literature investigating the impact of terrorism on business (e.g., Stergiou, 2016; Lin, 2020; Duru et al., 2020). Due to the increasing prevalence of terrorism around the world, understanding the consequences thereof for the business community within a society is important (Moser, 2020). The findings of this paper carry potential implications for investment practitioners, regulators, and academics. As Chen et al. (2020b) point out "the economics of security is one of the most important issues in our discipline, yet, the one least researched". In addition, in response to the recent call to study the firm-level consequences of terrorism in different countries (e.g., Chen et al., 2020c), this study provides insight into the impact of a modern terrorist group i.e., ISIS.

This article is structured as follows. Section 2 provides a background for the study and develops the research hypotheses. Section 3 describes the data and research methods employed. Sections 4 and 5 present the main results as well as additional analysis. Finally, section 6 provides concluding remarks.

\section{Institutional setting, literature review and hypotheses development}

\subsection{Institutional setting}

\subsubsection{Iraq Stock Exchange}

The Iraq Stock Exchange (ISX) is located in Baghdad (i.e., the capital of Iraq). It was established in 2004 and opened to international investors in 2007. Before the invasion of Iraq 
in 2003, the country's stock exchange was the Baghdad Stock Exchange, which was founded in 1991 and launched stock trading in 1992 with 64 listed firms. The ISX is considered as a self-regulatory organization governed by the Securities Commission of Iraq, the Iraqi version of the U.S. SEC. This commission serves as the bridge between the former state-owned stock exchange and the new independent stock exchange (e.g., Bradosti and Singh, 2015). The ISX operates electronic trading platforms provided by the NASDAQ, and currently lists over 100 firms with a total market capitalization of USD 10.5 billion as of year 2019 .

The ISX is relatively comparable to most Asian emerging capital markets. For instance, at a macro level, similar to most developing countries in the last decade, the Government of Iraq has implemented macro stabilization plans and liberalized financial and corporate systems, leading to improved market infrastructures to facilitate the flourishing of the ISX (Vandenbrink and Wei-Yen, 2015; OECD, 2017). Moreover, the Iraqi government has brought foreign debts under control, reduced inflation, and improved some key social and economic performance indexes. At a micro level, similar to most emerging capital markets, the number of Iraqi firms in the capital market has increased. The listed firms tend to have highly concentrated ownership structures.

As a relatively small and under-studied market, investigating the ISX may also help understand other similar frontier markets such as those in the Middle East and North Africa (MENA) including Bahrain, Morocco, Palestine, and Tunisia and even smaller markets such as those of Armenia, Cambodia, Cameroon, Cape Verde, Laos, Libya, Maldives, Mozambique, Namibia, Swaziland, Syria, and Tanzania (see FOX News, 2020, for details about the smallest capital markets around the world). However, although many Middle Eastern markets have been affected by the terrorist activities of ISIS, they have had the most negative impact on the ISX. Thus, the ISX can provide a unique setting for studying the impact of terrorism. 


\subsubsection{Islamic State of Iraq and Syria}

Terrorism and terroristic groups continue to be a problem for businesses around the world. Today, of the 162 countries tracked by the Institute for Economics and Peace, only 37 countries are free from incidents of terrorism (Institute for Economics and Peace, 2016). Among the terroristic groups, ISIS gained global prominence when it defeated and drove the Government of Iraq forces out of important Iraqi cities such as Mosul in 2015 (Carter et al., 2015). Nevertheless, the origins of ISIS may be traced back to 1999, when it was known as Jama'at al-Tawhid wal-Jihad. Then, it pledged allegiance to Al-Qaeda and was involved in joint operations with Al-Qaeda in Iraq after the US-led invasion of the country in 2003 (Zelin, 2014). ISIS grew under the Salafi/Wahhabi school of thought and prioritized its strategy towards destabilizing and replacing the governing status quo in Iraq and Syria. Having captured large swaths of territories in Iraq and Syria, ISIS expanded its goals to include the pursuit of a global caliphate; seeking the literal expansion of the caliphate and establishing a global radicalization effort that can be self-sustaining over generations (McFate, 2015). At the same time, the group built its strategy around uncompromising use of violence and a harsh ideology aimed at the creation of a long-term caliphate-one for the regional power centers, one for the Muslim world, and one for the non-Muslim world (Githing'u et al., 2020).

A moral panic has been created by the appeal of ISIS in face of the assumed superior values of neoliberal globalization and multiculturalism (Wood, 2015). This appeal is seemingly rather diverse, with recruits and supporters being drawn in from across the world. This has led to the organization being deemed as a global threat (Carafano, 2016). Utilizing remote sensing data and commercial satellite imagery, Robinson et al. (2019) provide a unique perspective on the internal situation in ISIS-controlled areas. It gives a clear picture of life in these areas which is characterized by electricity shortages, a large number of displaced people, reduced agricultural products, and increasing violence. While ISIS in Raqqa and Mosul, as its strategic 
capitals, helped stabilize local business by building some government structures, in other ISIScontrolled areas, the group has either neglected vital resources or replaced the government. Furthermore, the main reason for the economic collapse of ISIS was its inefficiency in separating its territory from the areas controlled by other armed opposition groups. In addition, external military pressure on ISIS also prevented the group from realizing its governmental ambitions across key parts of the so-called caliphate. This had major implications for the group's ability to support the performance of the local economy. Johnston (2014) and Stergiou (2016) note that ISIS spent its financial resources pursuing the following objectives: expanding its territorial bases in Iraq and Syria, expanding its influence across other strategic parts of MENA, and funding plots for attacks in North America, Western Europe or elsewhere.

\subsection{Literature review and hypotheses development}

Neoclassical economic theory suggests that managers, being homogeneous and rational optimizers, have a limited individual influence on corporate outcomes (e.g., Bertrand and Schoar, 2003). However, analytical studies (e.g., Rosen, 1981; Gabaix and Landier, 2008), consistent with human capital theory (e.g., Becker, 1964) and upper echelons theory (Hambrick and Mason, 1984), support the notion that managers can play a significant role in shaping corporate outcomes. A growing body of empirical studies examine the impact of managerial ability on corporate decisions and outcomes, such as investment efficiency (e.g., Habib and Hasan, 2017), credit rating (Cornaggia et al., 2017), tax avoidance (e., Park et al., 2015), executive compensation (Gan and Park, 2016), and firm performance (e.g., Chang et al. 2010). Accounting and financial scholars endeavor to explain why and how managers affect accounting choices. Particularly, positive accounting theory (PAT) attempts to explain and predict the accounting choices made by managers under different circumstances (Watts and Zimmerman, 1990). Consistent with PAT, managers may choose accounting practices for their own best interests and to maximize their utility (Scott, 2009), which is in line with 
agency theory. To clarify, accounting standards or requirements, for the sake of reporting efficiency, allow some flexibility to choose from a set of available accounting practices. This flexibility opens up the possibility of opportunistic behavior. Thus, in the process of analyzing costs and benefits of accounting decisions, managers may choose accounting practices for their own best interests and to maximize their utility (Silva et al., 2019).

Generally, in the context of managerial ability and corporate reporting, prior research argues that equity-based compensation incentivizes high-ability managers to improve corporate reporting quality (Milbourn, 2003). Trueman (1986) theorizes that because the market values information about firms' underlying economics, high-ability managers receiving equity-based compensation have incentives to inform the market about such information. Relatedly, Baik et al. (2011) report that managerial ability is positively related to the likelihood, accuracy, and value relevance of voluntary management earnings forecasts. In contrast, highability managers may increase their payoffs through opaque disclosures. Previous studies also argue that entrenched managers could extract a higher informational rent through the use opaque financial reporting (Bebchuk and Fried, 2004; Kalyta and Magnan, 2008).

Particularly, it is expected that managers significantly influence accounting choices and hence earnings quality. In this respect, the literature (e.g., DeJong and Ling, 2013; Francis et $a l ., 2020)$ indicates that managerial ability can play a key role in changing accounting choices, since managers can influence the implementation of accounting standards and the preparation of financial statements. Furthermore, career concerns and the external reputation of managers are shown to be key drivers of accounting choices (e.g., Graham et al., 2005).

There are plausible competing arguments over the direction of the association between managerial ability and earnings quality. The first perspective is that having a competent manager leads to a better understanding of business and industry resulting in better accounting choices, more reliable estimates, and also more accurate judgments about accruals (e.g., Baik 
et al., 2020). For instance, regarding the estimation of the provision for bad debt, less able managers may use the historical rate of bad debt, while more able managers may adjust the historical rate using factors such as macro-economic and industry trends, and changes in the entity's customer base (e.g., Demerjian et al., 2013). Thus, more able managers are expected to report higher quality earnings as they can better estimate earnings in complex situations. Furthermore, more able managers better understand the internal and external context of the company which leads to more accurate accruals. They can also more accurately identify profitable projects through their knowledge and experience, and by investing in them, they can improve operational cash flows (e.g., Demirjian et al., 2013), which in turn enhances earnings quality (e.g., Dechow and Dichev, 2002). Consistently, Wells (2020) shows that individual managers' fixed effects can explain a significant proportion of cross-sectional variation in earnings quality and Francis et al. (2020) demonstrate that better management leads to higher value relevance of earnings.

The second perspective is that more able managers raise their payoffs through opaque disclosures. Entrenched managers may extract higher information rent by way of providing opaque corporate reporting (e.g., Bebchuk and Fried, 2004; Kalyta and Magnan, 2008). There is also evidence that poor managers at the top provide inadequate monitoring resulting in a weak information environment (e.g., Klein, 2002) even though it may not be in the manager's best interests. Therefore, managers may play a negative role in the financial reporting process and exert significant influence on earnings through their operating decisions (Choi et al., 2015).

While in developed markets empirical evidence is consistent with a positive impact of managerial ability on earnings quality, there is scarce evidence in the context of emerging markets, particularly small markets, and the direction of the association between managerial ability and earnings quality is an empirical quandary. This is at least partly due to the high level of uncertainty in emerging markets (Bu et al., 2020), which can affect the relationship 
between managerial ability and earnings quality. El Ghoul et al. (2020) suggest that economic policy uncertainty (i.e., uncertainty about future government actions) may influence financial reporting choices through its impact on investors' attention to firmspecific information. This is because uncertainty may lead market participants to evaluate firms' disclosure quality more (less) closely, resulting in more (less) monitoring constraints on corporate actions and choices. Chen et al. (2020a) also argue that the effect of managerial ability is stronger in environments with higher macro uncertainty (such as economic policy uncertainty), as more able managers can more effectively manage the complexities of the business environment. Moreover, Bamber et al. (2010) argue that managers are not effectively interchangeable, and idiosyncratic differences in quality of management can lead them to make different choices, particularly in complex situations. This point is very relevant to emerging markets due to their higher complexities, information asymmetries, and a lack of transparency. As Nichols et al. (2009) point out, managers in emerging markets face higher levels of complexity arising from diverse types of risks such as exchange rate risk or liquidity risk. Bamber et al. (2010) suggest that in complex situations, managers' rational choices can be affected by managerial idiosyncratic experiences and values. Thus, in order not to lose stockholders' confidence in emerging markets and to avoid reputational damages (e.g., Singh and Misra, 2021), more able managers may have strong incentives to avoid negative earnings, which can affect their financial reporting choices and thereby earnings quality.

Based on the above discussions, it is expected that managerial ability significantly affects earnings quality of Iraqi firms. Since there are conflicting arguments and mixed empirical evidence, the first hypothesis is non-directional:

H1: Managerial ability significantly affects earnings quality of Iraqi firms.

This paper also examines whether and how ISIS influences the association between managerial ability and earnings quality. Theoretically, prior studies (e.g., Kim et al., 2015; 
Boone et al., 2018; Chen, 2019) suggest that terrorist attacks cause uncertainty, and in turn affect accounting choices and hence the association between managerial ability and earnings quality. There are two competing views about how ISIS may affect accounting choices by managers and earnings quality. First, consistent with the opportunistic perspective of PAT, higher uncertainty caused by ISIS provides an opportunity for managers not to prepare high quality information resulting in lower earnings quality. Kim et al. (2015) show that under the high levels of macroeconomic uncertainty, the likelihood of management forecast issuance is low. Moreover, Boone et al. (2018) demonstrate that managers decrease corporate information disclosure if they perceive a relatively high disclosure risk due to current uncertainty. Particularly, Duru et al. (2020) note that macroeconomic uncertainty driven by terrorist activities can negatively affect managers' perceptions of firm future performance and result in poor judgments and estimations which can affect accounting accruals. Moreover, managers in firms that suffer losses from actual incidents of terrorism have strong incentives to hide poor firm performance or financial distress through lower earnings quality (Moser, 2020). Moreover, they may further drive down earnings quality in an effort to obfuscate poor performance in order to avoid unstable operating conditions, declines in stock prices, and debt covenant violations, which can negatively affect managers' reputations and compensation as well as managerial turnover (DeFond and Jiambalvo, 1994; Cui et al., 2020). Relatedly, Iatridis (2012) and also Rachmawati and Adhariani (2019) indicate that managers may use discretionary accounting policies in order to mitigate the negative impact of a terrorist attack and maintain their current financial condition. Furthermore, under macroeconomic uncertainty caused by terrorism, managers can more easily influence accruals opportunistically and shift earnings from uncertain to more certain times (e.g., Stein and Wang, 2016). Ongsakul et al. (2020) also provide evidence highlighting that when terrorist attacks occur, managers have strong incentives to manipulate accruals as the market 
reaction to the attacks is substantially mitigated for firms with higher discretionary accruals. Cui et al. (2020) suggest that the impact of macroeconomic uncertainty on opportunistic managerial choices is more pronounced when monitoring mechanisms are weak. This is particularly relevant to small and emerging markets like the ISX, where monitoring and investor protection mechanisms are not strong.

Second, in line with the efficient perspective of PAT, high uncertainty caused by ISIS may lead to efficient accounting choices, resulting in high earnings quality. In line with this intuition, there is evidence that macroeconomic uncertainty may positively influence accounting choices as the uncertainty can lead market participants to evaluate firms' disclosure quality more closely, resulting in more monitoring constraints on accounting choices by managers, and hence less opportunistic behavior (e.g., El Ghoul et al., 2020). Cui et al. (2020) discuss that to reduce the negative impact of macroeconomic uncertainty, such as higher capital costs, managers are strongly motivated to provide high quality information (Verrecchia, 1990; Baker et al., 2016). Particularly, in the context of high macroeconomic uncertainty from terrorist activities, managers can easily attribute their poor performance to terrorist attacks (e.g., Chen et al., 2020b), therefore, they do not necessarily need to opportunistically influence accruals accounting. In addition, Schmid (2005) states that terrorist activities may cause managers to experience the psychological consequences of fear and pessimism making them more risk averse. This is particularly relevant to ISIS as it strategically and systematically seeks to create profound fear (Simons, 2018). Such tendency toward risk aversion may induce safer accounting choices by managers (Moser, 2020). For example, Cuculiza et al. (2020) document that managers who have experienced terrorist attacks are less likely to choose aggressive corporate policies, which improve accruals and earnings quality (Dechow et al., 2010; Francis et al., 2013; Zhong and Li, 2017). Similarly, Chen (2019) argues that managers affected by terrorist attacks are less likely to overestimate 
accruals. Lin (2020) further indicates that managers with higher risk aversion may prepare their financial reports more carefully.

Based on these two perspectives (i.e., opportunistic perspective versus efficient perspective), ISIS might negatively or positively affect accounting choices by managers, and thus, it can moderate the relationship between managerial ability and earnings quality. This leads to the second hypothesis which is also non-directional:

H2: The presence of ISIS moderates the relationship between managerial ability and earnings quality.

Prior studies (e.g., Ivković and Weisbenner, 2005; Defond et al., 2018) reveal the importance of geographical location in diverse contexts. For example, Defond et al. (2018) find that proximity to SEC offices make external auditors more aware of SEC scrutiny with regard misconduct. Particularly, in the context of terrorism, Cuculiza et al. (2020) document that analysts located close to terrorist attacks provide more pessimistic earnings forecasts. Further, Dai et al. (2020) note that managers of firms located close to terrorist attacks prefer cash-based compensation over more volatile equity-based compensation, suggesting that managers exposed to local attacks are more risk averse. In addition, there is evidence that the impact of terrorist attacks on residents' emotions decreases with the distance from terrorist attacks (Galea et al., 2002). Lin (2020) studies the impact of terrorist attacks on audit practices suggesting that terrorist attacks that occur within 10 miles of the auditors' office have the strongest impact. Relatedly, Chen et al. (2020b) reveal that the geographical distance between a firm and the location of terrorist attacks influences earnings disclosures.

Thus, consistent with arguments regarding the second hypothesis — including the opportunistic perspective versus the efficient perspective on ISIS impacts - it is expected that closeness to ISIS-controlled territories influences the association of managerial ability and earnings quality. This leads to the following hypothesis: 
H3: Geographical proximity to ISIS moderates the relationship between managerial ability and earnings quality.

Figure 1 summarizes the conceptual framework for hypotheses development.

(Please insert Figure 1 around here)

\section{Methodology}

\subsection{Sample and data}

This paper studies firms listed on the ISX including 84 active firms. Consistent with prior studies (e.g., Reeb and Zhao, 2013; Doukas and Zhang, 2020; Kontesa et al., 2020; Oskouei and Sureshjani, 2020), financial industries (38 firms) are excluded because they are different in nature. Firms with unavailable information (11 firms) are also deleted. The final sample includes 245 firm-years observations representing 35 unique firms for the period 2012 to 2018. The period 2012-2014 is considered as the pre-ISIS period, and 2015-2018 as the postISIS period.

\subsection{Variable definitions}

\section{Managerial ability}

Consistent with prior studies (e.g., Demerjian et al., 2013; Choi et al., 2015; Baik et al., 2020; Chen et al., 2020a; Doukas and Zhang, 2020; Francis et al., 2020; Luu et al., 2020; Oskouei and Sureshjani, 2020; Yung and Nguyen, 2020), our measure of managerial ability is determined using the model by Demerjian et al. (2012), which is also employed by research on Asian emerging and small capital markets such as Iran (Hesarzadeh, 2020), Pakistan (Inam Bhutta, 2021), Korea (Cho et al., 2018), and Taiwan (Choo et al., 2020). This model is based on data development analysis (DEA), which takes a non-linear optimization approach, enabling us to measure managerial ability based on the output generated by the firm from diverse input, 
and to benchmark the output against what could theoretically be generated (Baghdadi et al., 2018; Baik et al., 2020; Yung and Nguyen, 2020).

We estimate managerial ability through a two-step procedure. First, firm efficiency is operationalized through an optimization algorithm in which sales is the output and tangible and intangible assets, cost of inventory, $\mathrm{R} \& \mathrm{D}$, operating leases, and general \& administrative expenses are the input. The optimization algorithm can be run in two equivalent forms: output-oriented or input-oriented. This paper follows the prior literature and employs the input-oriented form (e.g., Baik et al., 2011; Demerjian et al., 2013). However, the outcomes these algorithms yield are identical (Cooper et al., 2006, p.105; Demerjian et al., 2013). Therefore, since firm efficiency reflects both managerial ability and also firm characteristics, we decompose the two by regressing firm efficiency on firm characteristics, including size, age, concentration of business segments, availability of cash, foreign transactions, and market share. The residual denotes the managerial ability score (M.Ability). Since DEA can be sensitive to outliers, following previous studies (e.g., Demerjian et al., 2013; Hesarzadeh, 2020; Yung and Nguyen, 2020), all output and input variables are winsorized at $1 \%$ tails.

\section{Earnings quality}

Earnings quality is measured by four widely used proxies (e.g., Dechow et al., 2010; Demerjian et al. 2012; 2017; Wells, 2020):

- Restate: A dummy variable that is equal to one if the firm restates its earnings, and zero otherwise.

- Persist: Earnings persistence is calculated using the following model:

$$
\text { Earnings }_{j t+1}=\alpha+\beta_{1} \text { Earnings }_{j t}+\varepsilon_{j t}
$$

Where Earnings is net profit, and $\beta_{1}$ denotes earnings persistence.

- AQ: Accruals quality is estimated following McNichols (2002): 


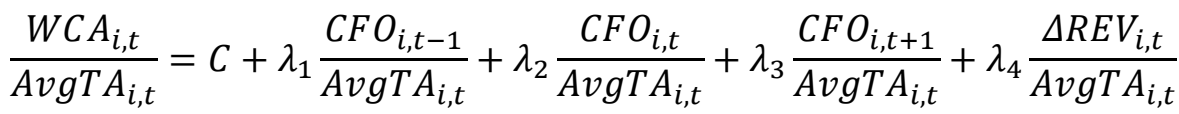

$$
\begin{aligned}
& +\lambda_{5} \frac{P P E_{i, t}}{\operatorname{AvgT~}_{i, t}}+\varepsilon_{i, t}
\end{aligned}
$$

Where $W C A$ denotes working capital accruals, $C F O$ is cash flow from operations, $\triangle R E V$ is change in sales, and $P P E$ is gross property, plant, and equipment. The residuals from the equation above is our measure of accruals quality: the lower the value, the higher accruals quality. The values are multiplied by minus one to ensure that we interpret higher values as higher accruals quality.

- ERC: Following Dechow et al. (2010), the following equation is used to measure earnings response coefficient:

$$
\text { Return }_{t+1, i}=a_{0}+a_{1} \text { Earnings }_{t, i}+\epsilon_{t, i}
$$

Where Return is the annual stock returns and $a_{1}$ indicates earnings response coefficient.

\section{ISIS and proximity to ISIS}

In the second and third hypotheses, there are two moderator variables i.e., the presence of ISIS and the geographical proximity to ISIS. ISIS is a dummy variable set equal to one for observations belonging to the post-ISIS period (i.e., 2015-2018), and zero otherwise. To operationalize the geographical proximity to ISIS, we use the median of distance from ISIS territories. $I S I S_{\text {proximity }}$ is a dummy variable set equal to one if the distance of firms headquarters from ISIS-controlled territories is above the median, and zero otherwise. It should be noted that $I S I S_{\text {proximity }}$ is calculated only for the post-ISIS period.

\section{Control variables}

Following prior studies (e.g., Dechow et al., 2010; Beck et al., 2012; Demerjian et al. 2012; 2017; Robinson et al. 2019; Wells, 2020), the following control variables are used.

- Firm Size measured as the natural logarithm of the firm's market value at the end of the year. 
- Sales Volatility measured as the standard deviation of the ratio of sales to total assets over the past three years.

- Cash Flow Volatility measured as the standard deviation of operational cash flow to total assets over the past three years.

- Operating Cycle measured as the logarithm of the sum of the ratio of receivables to sales and the ratio of inventories to the cost of goods sold.

- Big Auditor is a dummy variable set equal to one if a firm is audited by the Supreme Audit of Iraq, and zero otherwise.

- Loss is a dummy variable set equal to one if a firm reports a loss in the current year, and zero otherwise.

- Sales Growth measured as the percentage of change in sales.

- Return on Assets measured as income before extraordinary items divided by total assets.

\subsection{Empirical models}

The first hypothesis $(H 1)$ predicts that managerial ability significantly affects earnings quality. We use four proxies for measuring earnings quality, including earnings restatement, earnings persistence, accruals quality, and earnings response coefficient. Hence, to test $H 1$, we run the following four models (panel regressions):

$$
\begin{aligned}
& \text { Restate }_{t+1, i}=a_{0}+a_{1} \text { M.Ability }{ }_{t, i}+\text { Controls }+ \text { fixed effects }+\epsilon_{t, i} \\
& \text { Earnings }_{t+1, i}=a_{0}+a_{1} \text { Earnings }_{t, i}+a_{2} \text { M.Ability }_{t, i}+a_{3} \text { Earnings } \times \text { M.Ability }{ }_{t, i}+\text { Controls } \\
& + \text { fixed effects }+\epsilon_{t, i} \\
& A Q_{t+1, i}=a_{0}+a_{1} \text { M.Ability }{ }_{t, i}+\text { Controls }+ \text { fixed effects }+\epsilon_{t, i} \\
& \text { Return }_{t+1, i}=a_{0}+a_{1} \text { Earnings }_{t, i}+a_{2} \text { M.Ability }_{t, i}+a_{3} \text { Earnings } \times M \cdot \text { Ability }_{t, i}+ \\
& \text { Controls }+ \text { fixed effects }+\epsilon_{t, i}
\end{aligned}
$$

In all equations, Controls reflects control variables and fixed effects implies year and firm fixed effects. All variables are as previously defined.

To test the second hypothesis (H2), i.e., the impact of ISIS on the association of managerial ability and earnings quality metrics, based on Equations (1) to (4), the present study 
uses the following four models, respectively. In Equations (5) \& (7), $a_{3}$ shows how ISIS influences the association of managerial ability and earnings restatement $\&$ accruals quality. Further, in Equations (6) \& (8), $a_{5}$ displays how ISIS affects the association of managerial ability and earnings persistence \& earnings response coefficient (see for example, Burks et al. (2019) for details about interpreting regressions with interactions).

$$
\begin{aligned}
& \text { Restate }_{t+1, i}=a_{0}+a_{1} M . \text { Ability }_{t, i}+a_{2} I S I S_{t, i}+a_{3} M . \text { Ability } \times I S I S_{t, i}+\text { Controls }+ \text { fixed } \\
& \text { effects }+\epsilon_{t, i}
\end{aligned}
$$

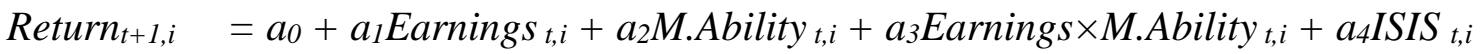

$$
\begin{aligned}
& +a_{5} I S I S \times \text { Earnings } \times \text { M.Ability } t, i+\text { Controls }+ \text { fixed effects }+\epsilon_{t, i}
\end{aligned}
$$

Finally, to test the third hypothesis (H3), i.e., the impact of the geographical proximity to ISIS on the association between managerial ability and earnings quality, we replace the variables $I S I S$ in equations (5) to (8) with $I S I S_{\text {proximity }}$ and re-run the models.

\section{Findings}

\subsection{Descriptive statistics}

Table 1 present descriptive statistics for the main variables. To minimize the impact of extreme values, all continuous variables are winsorized at $1 \%$ level. As the table shows, on average, $36 \%$ of companies have restated their earnings, and the mean of earnings persistence, accruals quality, and earnings response coefficient are $0.152,-0.069$, and 0.014 , respectively. Descriptive statistics suggest that earnings quality of Iraqi firms is poorer than its counterparts in large capital markets; for example, Bhattacharya et al. (2012) report that it is 0.030 in US firms. It is also lower than in other emerging markets (see, for example, Hesarzadeh (2020) who shows that the mean of $A Q$ is -0.054 for Iranian firms). The mean of managerial ability is -0.001, which is close to prior studies; for instance, Doukas and Zhang (2020) and Francis et al. 
(2020) report 0.012 and -0.006 , respectively. However, the standard deviation of managerial ability is approximately 0.363 , which is higher than that reported by prior studies. The mean of the ISIS dummy indicates that about $57 \%$ of firm-years observations belong to the ISIS periods.

(Please insert Table 1 around here)

\subsection{Inferential statistics}

\subsubsection{Managerial ability and earnings quality}

The first hypothesis predicts that managerial ability significantly affects earnings quality. To test this, using Equations (1) to (4) in section 3.3, the four measures of earnings quality are regressed on managerial ability. Table 2 reports the results. Following prior studies (e.g., Petersen 2009; Fernández Méndez et al. 2016), in all equations, standard errors are adjusted for heteroscedasticity and cross-sectional correlation by clustering at the firm level. As shown in the table, the coefficient on managerial ability (M.Ability) is negative (-0.172) in Equation (1) and positive (0.189) in Equation (3) and both coefficients are statistically significant at 5\% level. These suggest that higher managerial ability leads to lower earnings restatement and higher accruals quality. Furthermore, the coefficient on Earnings $\times$ M.Ability is positive and significant in Equations (2) and (4). This indicates that management ability has a significant effect on both earnings persistence and earnings response coefficient as the coefficients on Persist and ERC are 0.038 and 0.027 , respectively, and that both increase with managerial ability. Particularly, earnings persistence increases from 0.038 to $0.059(0.038+0.021)$ when moving from the lowest to the highest managerial ability. Similarly, earnings response coefficient increases from 0.027 to $0.041(0.027+0.014)$ when moving from the lowest to the highest managerial ability. These findings show that higher managerial ability leads to higher earnings persistence and earnings response coefficient, which is consistent with the first 
hypothesis. Overall, the results are consistent with human capital theory (e.g., Becker, 1964) and upper echelons theory (Hambrick and Mason, 1984), and support the notion that managers could play a significant role in shaping corporate outcomes.

(Please insert Table 2 around here)

\subsubsection{The Impact of ISIS}

The second hypothesis predicts that the presence of ISIS has a negative impact on the relationship between managerial ability and earnings quality. To test this, Equations (5) to (8) are run and the results are reported in Table 3. The table shows that the coefficients on ISIS $\times$ M.Ability are significant at 5\% in Equations (5) and (7) which suggests that ISIS moderates the association of managerial ability with earnings restatement and accruals quality. In Equation (5), the conditional coefficient on managerial ability (M.Ability) - the effect of managerial ability on earnings quality, when ISIS equals zero - is -0.183 which changes with ISIS; hence, the association between managerial ability and earnings restatement increases from -0.183 to $-0.091(-0.183+0.092)$ when moving from pre- to post-ISIS periods. This suggests that ISIS weakens the impact of managerial ability on earnings restatement. Similarly, in Equation (7), the coefficient on managerial ability decreases from 0.285 to $0.140(0.285-$ 0.145) when moving from pre- to post-ISIS, suggesting that ISIS weakens the impact of managerial ability on accruals quality.

The results reported for Equations (6) and (8) show that the coefficients on the Earnings $\times$ M.Ability $\times I S I S$ are statistically significant suggesting that ISIS moderates the association of managerial ability with earnings persistence and earnings response coefficient. For further clarification, in Equation (6), the conditional coefficient on the interaction between earnings and managerial ability (Earnings $\times$ M.Ability) - i.e., the conditional association between earnings persistence and managerial ability — is 0.093 , which changes with ISIS. Specifically, the conditional association of earnings persistence and managerial ability 
decreases from 0.093 to $0.041(0.093-0.052)$ when moving from pre- to post-ISIS. This suggests that ISIS reduces the impact of managerial ability on earnings persistence. Similarly, in Equation (8), the conditional coefficient on the interaction of earnings and managerial ability (Earnings $\times$ M.Ability) - i.e., the conditional association between earnings response coefficient and managerial ability - is 0.075 which decreases to $0.024(0.075-0.051)$ when moving from pre- to post-ISIS. This suggests that ISIS weakens the impact of managerial ability on earnings response. The coefficient on ISIS in all four equations shows that ISIS negatively affects earnings and returns (see Equations (6) and (8)) and also leads to higher earnings restatement and lower accruals quality (see Equations (5) and (7)).

Overall, the results demonstrate that the presence of ISIS has a significantly negative impact on the relationship between managerial ability and earnings quality, which is in line with the opportunistic perspective of PAT.

(Please insert Table 3 around here)

To examine the effect size of terrorism, following Dawson (2014), this paper plots the effect and computes $f^{2}$ which is the ratio of variance explained by the interaction term alone to the unexplained variance in Equations 5 to 8 . Figure 2 displays the plots and $f^{2}$. Consistent with previous findings, the figure visually shows that ISIS has a significantly negative impact on the relationship between managerial ability and earnings quality. For instance, as shown in the figure, the magnitude of the slope for the negative association between restatement and managerial ability is smaller in the ISIS period. Furthermore, the slope for the positive association between earnings persistence and managerial ability is smaller in the ISIS period. More importantly, $f^{2}$ s are higher than $10 \%$ which denotes that the strength of the moderating effect is economically significant. ${ }^{2}$

\footnotetext{
${ }^{2}$ Cohen (1988) suggests that effect sizes around 0.02, 0.15, and 0.35 may be labeled small, medium, and large, respectively.
} 


\subsubsection{The Impact of Proximity to ISIS Territories}

The third hypothesis predicts that the geographical proximity to ISIS has a significantly negative impact on the association between managerial ability and earnings quality. To empirically examine this, Equations (5) to (8) are run and the results are reported in Table 4. The table shows that the coefficients on M.Ability $\times I S I S$ proximity are significant at $5 \%$ in Equations (5) and (7) which suggests that the geographical proximity to ISIS moderates the association of managerial ability with earnings restatement and accruals quality. In Equation (5), the coefficient on M.Ability is -0.267 which increases to $-0.116(-0.267+0.151)$ when moving from the firms far from ISIS-controlled territory $\left(I S I S_{\text {proximity }}=0\right)$ to the firms closer to ISIS $\left(I S I S_{\text {proximity }}=1\right)$. This suggests that the geographical proximity to ISIS weakens the impact of managerial ability on earnings restatement. Similarly, in Equation (7), the association between managerial ability and accruals quality decreases from 0.506 to $0.158(0.506-0.348)$ when moving closer to ISIS, indicating that the geographical proximity to ISIS weakens the impact of managerial ability on accruals quality.

The results reported for Equations (6) and (8) show that the coefficients on Earnings $\times$ M.Ability $\times I S I S_{\text {proximity }}$ are statistically significant suggesting that the geographical proximity to ISIS moderates the association of managerial ability with earnings persistence and earnings response coefficient. In Equation (6), the coefficient on Earnings $\times$ M.Ability, i.e., the association between earnings persistence and managerial ability, is 0.079 which decreases to $0.007(0.079-0.072)$ when moving closer to ISIS territories. This indicates that the geographical proximity to ISIS weakens the impact of managerial ability on earnings response. Similarly, in Equation (8), the coefficient on Earnings $\times$ M.Ability, i.e., the association between earnings response coefficient and managerial ability, is 0.561 which decreases to 0.167 (0.556 - 0.389) when moving closer to ISIS-controlled territories. This suggests that the geographical proximity to ISIS weakens the impact of managerial ability on earnings response. 
Untabulated $f^{2} \mathrm{~s}$ for the moderating effects of the geographical proximity to ISIS are higher than $13 \%$ suggesting that the effects are economically significant.

Thus, taken together, the results reveal that the geographical proximity to ISIS has a negative impact on the association between managerial ability and earnings quality, which is consistent with the initial findings for the second hypothesis, i.e., the opportunistic perspective of PAT.

(Please insert Table 4 around here)

\section{Additional analysis}

\subsection{Alternative measures of managerial ability}

This section examines the robustness of results to the alternative measures of managerial ability used by prior studies (e.g., Reeb and Zhao, 2013; Hsieh et al., 2018, Lai et al., 2019; Kontesa et al., 2020). We use four measures of managerial ability including directors' networking or social capital (the number of corporate boards a director sits on during the year), educational capital (the number of directors with a graduated degree), expertise (the number of directors with expertise in five areas including law, investment bank, management consulting, and accounting), and working experience (the number of positions higher than vice president that directors have held during their lifetime). In this regard, first, borrowing insights from the literature, this study develops a composite measure of the alternative

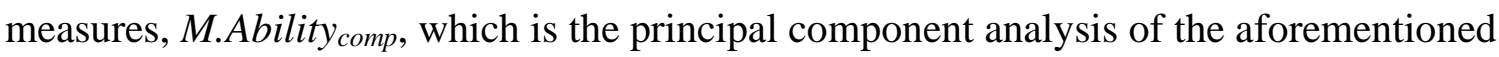
four measures. Then, the research hypotheses are re-examined using the new measures.

Table 5 reports the results for alternative measures of managerial ability. As the table shows, the number of observations has decreased significantly as a consequence of data unavailability. Nonetheless, the results suggest that the main findings are not sensitive to the use of alternative measures of managerial ability. 
(Please insert Table 5 around here)

\subsection{Addressing Potential Endogeneities}

ISIS may have simultaneously affected both managerial ability and earnings quality, which raises endogeneity concerns. To address this, following past research (e.g., Shipman et al., 2017), the propensity-score matching approach is employed. We first regress the dummy version of the managerial ability variable (M.Ability dummy $_{\text {) }}$ on ISIS and control variables (including market to book value, leverage, cash flow from operations, return on assets, annual management bonus, percentage of institutional ownership, and board independence (e.g., Demerjian et al., 2012; El Mahdy, 2019; Hesarzadeh, 2020). Then, obtaining the fitted (predicted) values from the aforementioned regression, each firm-year observation is matched to a firm-year observation with the closest fitted value in the same year and industry. Finally, the association between managerial ability and earnings quality is estimated using the matched sample.

The results are reported in Table 6. Panel A of the table shows that ISIS negatively affects managerial ability and Panel B indicates that M.Ability remains statistically significant for all four measures of earnings quality.

(Please insert Table 6 around here)

In addition to matching, we also use the difference-in-differences method to address endogeneity (e.g., Aier et al., 2014; Duru et al., 2020). To this end, we examine changes in earnings quality of firms exposed to ISIS (treatment group) relative to changes in the earnings quality of firms unexposed to it (control group). Using the median of geographical proximity, firms in the proximity of ISIS-controlled territories are considered as the treatment group and a matched sample of non-local firms within the same industry with a relatively similar size (i.e., maximum $10 \%$ difference) is considered as the control group, and the following models (which are based on Equations (5) to (8), are run: 


$$
\begin{aligned}
& \text { Restate }_{t+1, i}= a_{0}+a_{1} M . \text { Ability }_{t, i}+a_{2} I S I S_{t, i}+a_{3} \text { Local }+a_{4} I S I S_{t, i} \times{\text { Local } \times M . \text { Ability }_{t, i}+}+ \\
& \text { Controls }+\epsilon_{t, i}
\end{aligned}
$$

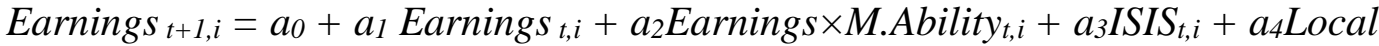

$$
\begin{aligned}
& +a_{5} \text { ISIS } \times \text { Local } \times \text { Earnings } \times \text { M.Ability }_{t, i}+\text { Controls }+\epsilon_{t, i}
\end{aligned}
$$

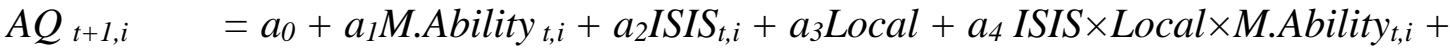

$$
\begin{aligned}
& \text { Controls }+\epsilon_{t, i} \\
& \text { Return }_{t+1, i}=a_{0}+a_{1} \text { Earnings }_{t, i}+a_{2} \text { Earnings } \times \text { M.Ability }_{t, i}+a_{3} I S I S_{t, i}+a_{4} \text { Local } \\
& +a_{5} I S I S \times \text { Local } \text { Earnings } \times \text { M.Ability } t, i+\text { Controls }+\epsilon_{t, i}
\end{aligned}
$$

Where $L O C A L$ is an indicator variable set equal to one for the firms close to ISIS-

controlled territories, and zero otherwise. It should be noted that $L O C A L$ is different from $I S I S_{\text {proximity }}$ as it is not limited to the years after the emergence of ISIS, but it is limited to the matched observations. In regressions (9) \& (11), the coefficient $a_{4}$ on ISIS $\times$ Local $\times$ M.Ability captures the difference-in-difference impact of ISIS on the association of managerial ability with restatement/accruals quality. Similarly, in regressions (10) \& (12), the coefficient $a_{5}$ on $I S I S \times$ Local $\times$ Earning $s \times M$.Ability captures the difference-in-difference impact of ISIS on the association of managerial ability with earnings persistence and earnings response coefficient. All other variables are as previously defined.

Table 7 reports the results. The coefficients on both interaction variables (i.e., $I S I S \times$ Local $\times$ M.Ability and ISIS $\times$ Local $\times$ Earning $\times$ M.Ability) are statistically significant which suggests that similar to the main results, ISIS affects the relationship between managerial ability and earnings quality. ${ }^{3}$

(Please insert Table 7 around here)

\footnotetext{
${ }^{3}$ Notably, while using instrumental variable (IV) and generalized method of moments (GMM) approaches are applicable for addressing potential endogeneities, prior studies show that the approaches are likely to produce estimates with less estimation error than propensity-score matching and difference-indifferences methods only under the most ideal circumstances. For example, it is hard to find variables that meet the definition of valid instruments (e.g., Larcker et al., 2007; Baser, 2009). Conceptually, most variables that have an effect on treatment variables may also have a direct effect on the outcomes variable in accounting research (e.g., Gippel et al., 2015), especially in this paper, where there are diverse dependent variables. Moreover, in small sample sizes, the IV and GMM approaches can be highly inaccurate (e.g., Grootendorst, 2007; Bascle, 2008).
} 


\subsection{How macroeconomic variables affect research results}

As previously explained, this paper theoretically argues that macroeconomic uncertainty driven by terrorist activities can affect managers' judgments and estimations which can thus affect accounting choices. In this line, this section examines the robustness of results to the inclusion of macroeconomic variables in empirical models. Thus, following the literature (e.g., Chappell et al., 1993; Kim et al., 2015; Bianchi et al., 2019), the current paper employs four key macroeconomic variables including gross domestic product growth $(G D P)$, inflation rate (Inflation), exchange rate (Exchange), and unemployment rate (Unemployment). Thereafter, the research hypotheses are re-examined using these new control variables.

Table 8 reports the results. Specifically, Panel A (B) presents the results on the moderating role of ISIS (proximity to ISIS) after the inclusion of macroeconomic variables in empirical analyses. The results suggest that while generally the macroeconomic variables may significantly influence dependent variables, the impact of ISIS and also the proximity to ISIS on the relationship between managerial ability and earnings quality is still significant. Therefore, the main findings are not sensitive to the inclusion of macroeconomic variables in the empirical analysis.

(Please insert Table 8 around here)

\section{Conclusion}

This paper examines the impact of managerial ability on earnings quality of listed Iraqi firms and how ISIS affects the association between managerial ability and earnings quality. The results indicate that managerial ability leads to lower earnings restatements, higher earnings persistent, higher accruals quality, and stronger earnings response coefficient. These findings are consistent with prior studies (e.g., Demerjian et al., 2017; Hesarzadeh, 2020) suggesting that managerial ability affects corporate reporting. Furthermore, the results indicate that the 
presence of ISIS and geographical proximity to ISIS weakens the relationship between managerial ability and earnings quality. These results are also consistent with recent evidence (e.g., Duru et al., 2020, Lin, 2020) that negative emotions caused by terrorism can affect corporate reporting choices. These results are robust to alternative measures of managerial ability and to various approaches used to address endogeneity.

This study contributes to the broad literature on managerial attributes and corporate policies (e.g., García-Meca and García-Sánchez, 2018; Doukas and Zhang, 2020), as it extends our understanding of the association between managerial ability and earnings quality in an understudied emerging market. More importantly, it extends the recent empirical evidence on the impact of terrorism on capital markets at the firm level (e.g., Chen et al., 2020a; Duru et al, 2020; Hills et al., 2020). The findings of this study may also enhance our understanding of the economic and social consequences of other kinds of terrorist activities. In addition, this paper adds to the literature on the impact of geographical location on corporate behavior (e.g., Dai et al., 2020) as it indicates that the geographical proximity to ISIS has a negative effect on the relationship between managerial ability and earnings quality.

This study has some limitations. First, the research sample is limited to a small, emerging capital market, thus the results may not be generalizable to large capital markets. Second, the sample is limited to a relatively short time period. While this is consistent with the nature of our event study, we encourage readers to exercise caution about the long-term effects of terroristic activities. Third, four measures of earnings quality are tested in this study so the results may not be generalizable to other measures. Fourth, although Demerjian's measure of managerial ability used in this study is one of the most widely employed in the literature (e.g., Luu et al., 2020), it is an approximate measure for managerial performance, hence the possibility that the measure may include idiosyncratic abnormal performance cannot be ruled out. Moreover, this measure does not include human capital ability which is conceptualized by prior literature (e.g., Hambrick and 
Mason, 1984). In addition, the measure is about how effective managers use input resources to generate output, therefore, if the input/output is different, or if a firm is added or eliminated the ability score will be different. Nevertheless, since the main findings are robust to alternative measures of managerial ability, the limitations of Demerjian's measure does not affect our main results.

Generally, the evidence from the current paper may help standard setters and policy makers in small emerging markets to better understand corporate reporting behavior in terms of managerial ability. Particularly, the findings of this paper about the roles of ISIS carry potential implications for practitioners, regulators, and academics, as "the economics of security is one of the most important issues in our discipline, yet, the one least researched" (Chen et al., 2020a). Given the obvious increase in terrorist activities in recent years (e.g., Miller, 2016), this paper suggests that investors and regulators should be vigilant of the negative impact of terrorist activities or geographical proximity to terrorist groups/activities on the accounting choices by managers when assessing the costs of terrorism and developing policies. In addition, in response to recent calls to study the firm-level consequences of terrorism in different countries (e.g., Chen et al., 2020b), this paper would provide beneficial insights on the role of a modern terrorist group, ISIS.

Nevertheless, this paper encourages future research to examine how terrorism may influence the association of managerial ability and other important accounting variables (such as real accruals management) and also the infrastructure choices (such as internal control quality) that have been shown to influence earnings quality. Further, this study does not investigate the reasons behind the negative impact of ISIS on earnings quality. This could be due to a political connection between Iraqi firms and ISIS which could also be addressed by future research. Moreover, the extent to which the results of this study can be extended to large capital markets is not clear, which could also be investigated by future studies. Future 
research may also examine how managerial ability interacts with firm characteristics such as corporate governance and corporate social responsibility, and how this association is affected by terrorism. 


\section{References}

Aier, J. K., Chen, L., \& Pevzner, M. (2014). Debtholders' demand for conservatism: Evidence from changes in directors' fiduciary duties. Journal of Accounting Research, 52(5), 993-1027.

Baghdadi, G. A., Bhatti, I. M., Nguyen, L. H. G., \& Podolski, E. J. (2018). Skill or effort? Institutional ownership and managerial efficiency. Journal of Banking \& Finance, 91, 19-33.

Baik, B., D. B. Farber, \& S. L., 2011. CEO ability and management earnings forecasts. Contemporary

Accounting Research, 28 (5): 1645-1668

Baik, B., Choi, S., \& Farber, D. B. (2020). Managerial ability and income smoothing. The Accounting Review, 95(4), 1-22.

Baker, M., Ruback, R. S., \& Wurgler, J. (2006). Behavioral corporate finance. Handbook of Corporate Finance: Empirical Corporate Finance, Volume A (Handbooks in Finance, Elsevier/North-Holland).

Bamber, L., Jiang, J., \& Wang, I. (2010). What's my style? The influence of top managers on voluntary corporate financial disclosure. The Accounting Review, 85, 1131-1162.

Bascle, G. (2008). Controlling for endogeneity with instrumental variables in strategic management research. Strategic Organization, 6(3), 285-327. doi:10.1177/1476127008094339

Baser, O. (2009). Too much ado about instrumental variable approach: Is the cure worse than the disease? Value in Health, 12(8), 1201-1209. doi:10.1111/j.1524-4733.2009.00567.x

Bebchuk, L., \& Fried, J. (2004). Stealth compensation via retirement benefits. Berkeley Business Law Journal, 1, 291-326.

Becker, G.S., 1964. Human capital theory. Columbia, New York, 1964.

Bertrand, M., and Mullainathan, S. (2003). Enjoying the quite life? Managerial behavior following antitakeover legislation. Journal of Political Economy, 111: 1042-1075

Bhattacharya, N., Ecker, F., Olsson, P. M., \& Schipper, K. (2012). Direct and mediated associations among earnings quality, information asymmetry, and the cost of equity. The Accounting Review, 87(2), 449-482.

Boone, A. L., Kim, A., \& White, J. T. (2018). Political Uncertainty and Firm Disclosure. SSRN Electronic Journal.

Bradosti., H., \& Singh, U. (2015). Public awareness of financial market in Iraqi Kurdistan. European Journal of Business and Management, 7 (10), 300-308

Bu, D., Zhang, C., Lin, P. T., \& Hu, F. (2020). Political uncertainty, institutions and accounting conservatism: evidence from the provincial leader turnover in China. Spanish Journal of Finance and Accounting, 49(4), 395-426.

Burks, J. J., Randolph, D. W., \& Seida, J. A. (2019). Modeling and interpreting regressions with interactions. Journal of Accounting Literature, 42, 61-79.

Carafano, J. 2016. "What makes ISIS a global threat, Forbes.” Accessed October 18, 2017. https://www.forbes.com/sites/jamescarafano/2016/03/16/whatmakes- isis-a-globalthreat/\#703059283629.

Carter, C. J., H. Alkhshali, and S. Capelouto. (2014). "Kerry assures Iraqis of US support if they unite against militias, CNN." Accessed October 26, 2017. http://edition.cnn.com/2014/06/23/world/meast/iraq-crisis.

Chan, K., Chan, K. C., Jegadeesh, \& N., Lakonnishok. (2006). Earnings Quality and Stock Returns. Journal of Business. Vol. 79(3): 1-42.

Chang, Y. Y., Dasgupta, S., \& Hilary, G. (2010). CEO ability, pay, and firm performance. Management Science, 56(10), 1633-1652.

Chen, C., Huang, A.G. \& Jha, R. (2012),. "Idiosyncratic return volatility and the information quality underlying managerial discretion”, Journal of Financial and Quantitative Analysis, Vol. 47 No. 4, pp. 873-899.

Chen, M., Ruan, L., Zhu, Z., \& Sang, F. (2020a). Macro uncertainty, analyst performance, and managerial ability. Eurasian Business Review, 10(3), 333-353.

Chen, W., H. Wu, and L. Zhang (2020b). Terrorist attacks, managerial sentiment, and corporate disclosures. The Accounting Review, Forthcoming. doi:10.2308/tar-2017-0655.

Chen, X. (2019). Managerial sentiment and non-GAAP earnings disclosure: evidence from terrorist attacks. AsiaPacific Journal of Accounting \& Economics, 1-19.

Chen, Y., Goyal, A., Veeraraghavan, M., \& Zolotoy, L. (2020c). Terrorist attacks, investor sentiment, and the pricing of initial public offerings. Journal of Corporate Finance, 65, 101780.

Cho, H., Choi, S., \& Kim, M.-O. (2018). Cash Holdings Adjustment Speed and Managerial Ability. Asia-Pacific Journal of Financial Studies, 47(5), 695-719.

Choi, W., Han, S., Jung, S. H., and Kang T. (2015). CEO's operating ability and the association between accruals and future cash flows. Journal of Business Finance \& Accounting, 42(5-6), 619-634.

Choo, M.-R., Wang, C.-W., Yin, C., \& Li, J.-L. (2020). Managerial ability and external financing. Asia-Pacific Financial Markets. doi:10.1007/s10690-020-09313-5

Cohen, J. (1988). Statistical power analysis for the behavioral sciences (2nd ed.). Hilllsdale, NJ: Erlbaum. 
Cooper, W., Seiford, L., \& Tone, K. (2006). Introduction to Data Envelopment Analysis and Its Uses. Springer: New York, NY.

Cornaggia, K. J., Krishnan, G. V., \& Wang, C. (2017). Managerial ability and credit ratings. Contemporary Accounting Research, 34(4), 2094-2122.

Cuculiza, C., Antoniou, C., Kumar, A., \& Maligkris, A. (2020). Terrorist attacks, analyst sentiment, and earnings forecasts. Management Science. doi:10.1287/mnsc.2019.3575

Czinkota, M. R., Knight, G., Liesch, P. W., \& Steen, J. (2010). Terrorism and international business: A research agenda. Journal of International Business Studies, 41(5), 826-843.

Dai, Y., Rau, P. R., Stouraitis, A., \& Tan, W. (2020). An ill wind? Terrorist attacks and CEO compensation. Journal of Financial Economics, 135(2), 379-398.

Dawson, J. F. (2014). Moderation in Management Research: What, Why, When, and How. Journal of Business and Psychology, 29(1), 1-19.

Dechow, P., Ge, W. \& Schrand, C. (2010). Understanding Earnings Quality: A Review of the Proxies, Their Determinants and Their Consequences, Journal of Accounting and Economics, Vol. 50, pp. 344-401.

Defond, M. L., Francis, J. R., \& Hallman, N. J. (2018). Awareness of SEC Enforcement and Auditor Reporting Decisions. Contemporary Accounting Research, 35(1), 277-313.

DeJong, D. and Ling, Z. (2013). Managers: their effects on accruals and firm policies. Journal of Business Finance \& Accounting, 40 (1-2), 82-114.

Demerjian, P., B. Lev, M. Lewis, \& S. MacVay. (2013). Managerial ability and Earnings quality. The Accounting Review, 88(2): 463-498.

Demerjian, P., Lev, B., \& McVay, S. (2012). Quantifying managerial ability: A new measure and validity tests. Management Science, 58(7), 1229-1248.

Demerjian, P., Lewis-Western, M., \& McVay, S. (2017). How does intentional earnings smoothing vary with managerial Ability? Journal of Accounting, Auditing \& Finance, 35(2), 406-437.

Doukas, J. A., \& Zhang, R. (2020). Corporate managerial ability, earnings smoothing, and acquisitions. Journal of Corporate Finance, 65, 101756.

Duru, A., Fan, Y., Pirinsky, C. A., \& Pevzner, M. (2020). Terrorism activities and management forecasts. SSRN Electronic Journal. doi:10.2139/ssrn.3513352

El Ghoul, S., Guedhami, O., Kim, Y., \& Yoon, H. J. (2020). Policy uncertainty and accounting quality. The Accounting Review. doi:10.2308/tar-2018-0057

El Mahdy, D. (2019). The unintended consequences of voluntary adoption of claw back provisions on managerial ability. Accounting \& Finance. doi:10.1111/acfi.12528

Fernández Méndez, C., Pathan, S., \& Arrondo, R., (2016). Monitoring capabilities of busy and overlap directors: Evidence from Australia. Pacific-Basin Finance Journal, 35, 444-469.

FOX News. (2020). World's smallest stock markets. Retrieved from https://www.foxbusiness.com/markets/worlds-smallest-stock-markets-exchanges-you-have-probablynever-heard-of

Francis, B., H, Iftekhar, S, Ibrahim, \& W, Qiang. (2020). "Managerial ability and value relevance of earnings". China Accounting and Finance Review, Forthcoming.

Francis, B., H, Iftekhar, S, Ibrahim, \& W, Qiang. (2020). "Managerial ability and value relevance of earnings". China Accounting and Finance Review, Forthcoming.

Francis, B., Hasan, I., \& Wu, Q. (2013). The Benefits of Conservative Accounting to Shareholders: Evidence from the Financial Crisis. Accounting Horizons, 27(2), 319-346.

Francis, B., Ren, N., Sun, X., and Wu, Q. (2017). Do better managers get better loan contracts? Working paper, Rensselaer Polytechnic Institute.

Francis, B., Ren, N., Sun, X., and Wu, Q. (2017). Do better managers get better loan contracts? Working paper, Rensselaer Polytechnic Institute.

Gabaix, X., and Landier, A. (2008). Why has CEO pay increased so much? Quarterly Journal of Economics, $123,49-100$.

Galea, S., J. Ahern, H. Resnick, D. Kilpatrick, M. Bucuvalas, J. Gold, and D. Vlahov (2002). Psychological sequelae of the September 11 terrorist attacks in New York City. New England Journal of Medicine, 346 (13), 982-987.

Gan, H., \& Park, M. S. (2016). Are more able CEOs getting more compensated? Evidence from the pay-forperformance sensitivity of equity-based incentives. Advances in Accounting, 34, 64-76.

García-Meca, E., \& García-Sánchez, I.-M. (2018). Does managerial ability influence the quality of financial reporting? European Management Journal, 36(4), 544-557.

Gippel, J., Smith, T., \& Zhu, Y. (2015). Endogeneity in Accounting and Finance Research: Natural Experiments as a State-of-the-Art Solution. Abacus, 51(2), 143-168. doi:10.1111/abac.12048 
Githing'u, B. M., Nganje, F., \& Omenma, J. T. (2020). Measuring the success of the Islamic State in Iraq and Syria: findings on the strategic and tactical outcomes of the uses of terrorism. Innovation: The European Journal of Social Science Research, 1-21. doi:10.1080/13511610.2020.1774355

Graham, J.R., Harvey, C.R., \& Rajgopal, S., (2005). The economic implications of corporate financial reporting. Journal of Accounting and Economics. 40 (1-3), 3-73

Grootendorst, P. (2007). A review of instrumental variables estimation of treatment effects in the applied health sciences. Health Services and Outcomes Research Methodology, 7(3-4), 159-179. doi:10.1007/s10742007-0023-6

Habib, A., \& Hasan, M. M. (2017). Managerial ability, investment efficiency and stock price crash risk. Research in International Business and Finance, 42, 262-274.

Hambrick, D.C. and Mason, P.A. (1984). Upper echelons: The organization as a reflection of its top managers. Academy of management review, 9(2), 193-206.

Hesarzadeh, R. (2020). Regulatory oversight and managerial ability. Eurasian Business Review, 10(4), 559-585.

Hills, R., Kubic, M., \& Mayew, W. J. (2020). State sponsors of terrorism disclosure and SEC financial reporting oversight. SSRN Electronic Journal. doi:10.2139/ssrn.3592694

Hribar, P. (2017). Does managerial sentiment affect accrual estimates? Evidence from the banking industry. Journal of Accounting and Economics, 63(1), 26-50.

Hsieh, Y. T., Chen, T. K., Tseng, Y. J., \& Lin, R. C. (2018). Top management team characteristics and accrualbased earnings management. The International Journal of Accounting, 53(4), 314-334.

Huang, X. (Sharon), \& Sun, L. (2017). Managerial ability and real earnings management. Advances in Accounting, 39, 91-104.

Hurley, P. J., B. W. Mayhew, K. Obermire, and A. Tegeler (2019). The impact of managers' risk aversion and loss aversion on audit quality demand. Unpublished Working Paper. doi:10.2139/ssrn.3425666

Iatridis, G. (2012). Terrorist attacks and company financial numbers: Evidence on earnings management and value relevance from Madrid, London and Istanbul. Research in International Business and Finance, 26(2), 204-220.

Inam Bhutta, A., Sheikh, M. F., Munir, A., Naz, A., \& Saif, I. (2021). Managerial ability and firm performance: Evidence from an emerging market. Cogent Business \& Management, 8(1), 1879449.

Institute for Economics and Peace (IEP). 2016.Global Peace Index. Sydney, Australia: Institute for Economics and Peace

Ivković, Z., \& S.Weisbenner. (2005). Local does as local is: information content of the geography of individual investors' common stock investments. The Journal of Finance 60 (1): 267-306

Johnston, P. B. (2014). Countering ISIL'S financing. RAND Office of External Affaires. November 13. http://www.rand.org/content/dam/rand/pubs/testimonies/CT400/CT419/RAND_CT419.pdf (accessed 02 Jun 2015).

Kalyta, P., \& Magnan, M. (2008). Executive pensions, disclosure quality, and rent extraction. Journal of Accounting and Public Policy, 27, 133-166.

Klein, A. (2002). Audit committee, board of director characteristics, and earnings management. Journal of Accounting and Economics, 33, 375-400.

Kontesa, M., Lako, A., \& Wendy, W. (2020). Board capital and earnings quality with different controlling shareholders. Accounting Research Journal, 33(4/5), 593-613.

Krishnan, G., and C. Wang. (2015). The relation between managerial ability and audit fees and going concern opinions. Auditing: A Journal of Practice and Theory, 34 (3): 139-160.

Kuhnen, C. M. and B. Knutson (2005). The neural basis of financial risk taking. Neuron 47 (5), 763-770.

Kuhnen, C. M. and B. Knutson (2011). The influence of affect on beliefs, preferences, and financial decisions. Journal of Financial and Quantitative Analysis, 46 (3), 605-626.

Lai, J.-H., Chen, L.-Y., \& Song, S. (2019). How outside directors' human and social capital create value for corporate international investments. Journal of World Business, 54(2), 93-106.

Larcker, D. F., \& Rusticus, T. O. (2007). Endogeneity and Empirical Accounting Research. European Accounting Review, 16(1), 207-215. doi:10.1080/09638180701269905

Lerner, J. S., and D. Keltner. (2001). Fear, anger, and risk. Journal of Personality and Social Psychology, 81 (1): 146

Lin, P. (2020). Do Emotions affect audit practice? Terrorist attacks and accounting misstatements. SSRN Electronic Journal. doi:10.2139/ssrn.3682870

Loewenstein, G. F., Weber, E. U., Hsee, C. K., \& Welch, N. (2001). Risk as feelings. Psychological Bulletin, 127(2), 267-286.

Luu, H. N., Doan, T. N., \& Anh, P. T. H. (2020). Managerial ability and bank failure. Applied Economics Letters, 1-5. doi:10.1080/13504851.2020.1752892

Matsunaga, Steven R. and Yeung, P. Eric, Evidence on the impact of a CEO's financial experience on the quality of the firm's financial reports and disclosures (October 30, 2008). AAA 2008 Financial 
Accounting and Reporting Section (FARS) Paper, Available at SSRN: https://ssrn.com/abstract=1014097 or http://dx.doi.org/10.2139/ssrn.1014097

McFate., J. L. (2015). The ISIS Defense in Iraq and Syria, Institute for the Study of War.

Milbourn, T. T. (2003). CEO reputation and stock-based compensation. Journal of Financial Economics, 68(2), 233-262.

Moser, W. J. (2020). Audit Pricing of Terrorism. AUDITING: A Journal of Practice \& Theory, 39(2), $163-184$.

OECD (2017), “OECD equity markets review: Asia 2017”, available at: www.oecd.org/corporate/OECDEquityMarkets-Review-Asia-2017.pdf

Ongsakul, V., Jiraporn, P., \& Kim, Y. S. (2020). The effect of earnings management on shareholder value and the role of board gender diversity. Pacific Accounting Review, 32(3), 323-334.

Oskouei, Z. H., \& Sureshjani, Z. H. (2020). Studying the relationship between managerial ability and real earnings management in economic and financial crisis conditions. International Journal of Finance \& Economics. doi:10.1002/ijfe.2031

Park, J., Ko, C. Y., Jung, H., \& Lee, Y.-S. (2015). Managerial ability and tax avoidance: evidence from Korea. Asia-Pacific Journal of Accounting \& Economics, 23(4), 449-477.

Petersen, M. A. (2009). Estimating standard errors in finance panel data sets: Comparing approaches. Review of Financial Studies, 22(1), 435-480.

Rachmawati, J. R. \& Adhariani, D. (2019). Bomb Attacks and Earnings Management: Evidence from Indonesia. International Journal of Business and Society, 20, 1-18

Reeb, D. M., \& Zhao, W. (2013). Director capital and corporate disclosure quality. Journal of Accounting and Public Policy, 32(4), 191-212.

Robinson, E., Egel, D., Johnston, P. B., Mann., S., Rothenberg, A. D., \& Stebbins, D. (2019). When the Islamic State Comes to Town: The Economic Impact of Islamic State Governance in Iraq and Syria. RAND Corporation, Santa Monica, Calif

Rosen, Sherwin, (1981). The economics of superstars. American Economic Review, 71, 845-858.

Schlenger, W. E., Caddell, J. M., Ebert, L., Jordan, B. K., Rourke, K. M., Wilson, D., Thalji, L., Dennis, J. M., Fairbank, J. A., and Kulka, R. A. (2002). Psychological reactions to terrorist attacks. JAMA 288 (5), 581.

Schmid, A. (2005). Terrorism as psychological warfare. Democracy and Security, 1 (2): 137-146.

Schrand, C. M., and S. L. C. Zechman. (2012). Executive overconfidence and the slippery slope to financial misreporting. Journal of Accounting and Economics, 53 (1): 311-329.

Scott, W. R. (2009). Financial Accounting Theory. 5th Edition, Pearson Prentice Hall, Ontario.

Sen, P. K. (2005). Reported Earnings Quality Under Conservative Accounting and Auditing. Journal of Accounting, Auditing \& Finance, 20(3), 229-256.

Shan, Y., Taylor, S. L., \& Walter, T. S. (2013). Fundamentals or managerial discretion? The relationship between accrual variability and future stock return volatility. Abacus, 49(4), 441-475.

Shipman, J. E., Swanquist, Q. T., \& Whited, R. L. (2017). Propensity score matching in accounting research. The Accounting Review, 92(1), 213-244.

Silva, A. H. C. e, Sancovschi, M., \& Santos, A. G. C. dos. (2019). The opportunistic approach of the Positive Accounting Theory (PAT) fails to explain choices made at OGX: An anomalous situation? Revista de Contabilidade e Organizações, 13, e164412.

Simons, G. (2018). Brand ISIS: Interactions of the tangible and intangible environments. Journal of Political Marketing, 17(4), 322-353.

Singh, K., \& Misra, M. (2021). Linking Corporate Social Responsibility (CSR) and Organizational Performance: the moderating effect of corporate reputation. European Research on Management and Business Economics, 27(1), 100139.

Stergiou, D. (2016). ISIS political economy: financing a terror state. Journal of Money Laundering Control, 19(2), $189-207$.

Sun, L. (2017). Managerial ability and chemical releases. Sustainability Accounting Management and Policy Journal, 8(3), 281-306.

Trueman, B. (1986). Why do managers voluntarily release earnings forecasts? Journal of Accounting and Economics, 8(1), 53-71.

Valasik, M., \& Phillips, M. (2017). Understanding modern terror and insurgency through the lens of street gangs: ISIS as a case study. Journal of Criminological Research, Policy and Practice, 3(3), 192-207.

Vandenbrink, D. and Wei-Yen, D. H. (2015). Capital markets in Asia: changing roles for economic development. institute of Southeast Asian studies", available at: https://bookshop.iseas.edu.sg/ publication/1006.

Watts, R.L. and Zimmerman, J. L., 1990. Positive accounting theory: a ten-year perspective. The Accounting Review, 65, 131-156.

Wells, K. (2020). Who Manages the Firm Matters: The Incremental Effect of Individual Managers on Accounting Quality? The Accounting Review, 95(2), 365-384. 
Wood, G. 2015. "What ISIS really wants, The Atlantic." Accessed October 18, 2017. https://www.theatlantic.com/magazine/archive/2015/03/what-isisreally-wants/384980/.

Yung, K., \& Chen, C. (2018). Managerial ability and firm risk-taking behavior. Review of Quantitative Finance and Accounting, 51(4), 1005-1032.

Yung, K., \& Nguyen, T. (2020). Managerial ability, product market competition, and firm behavior. International Review of Economics \& Finance, 70, 102-116.

Zelin, A. Y. (2014). The war between ISIS and al-Qaeda for supremacy of the global jihadist movement." Research Notes, Washington Institute for Near East Policy. 20 (1), 1-11.

Zhong, Y., \& Li, W. (2017). Accounting Conservatism: A Literature Review. Australian Accounting Review, $27(2), 195-213$. 
Figure 1: Summary of theoretical arguments for research hypotheses

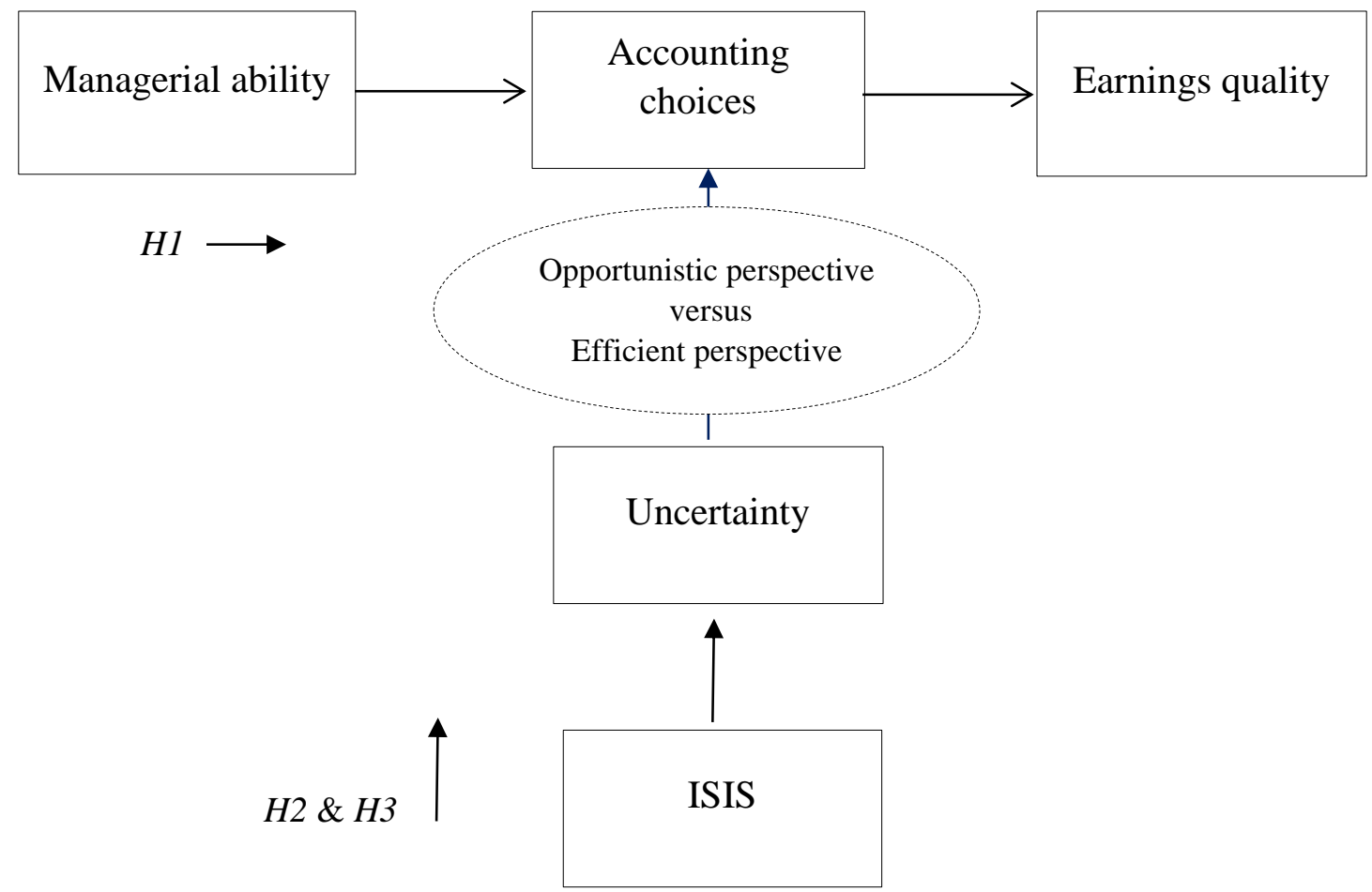

Notes: This figure summarizes theoretical arguments for the research hypotheses. 
Table 1: Descriptive statistics

\begin{tabular}{lccccc}
\hline Variable & Mean & Median & STD & Min & Max \\
\hline Restate & 0.363 & 0.000 & 0.482 & 0.000 & 1.000 \\
Persist & 0.152 & 0.159 & 0.151 & -0.219 & 0.708 \\
$A Q$ & -0.069 & -0.074 & -0.282 & -0.312 & 0.000 \\
ERC & 0.014 & 0.018 & 0.430 & -0.013 & 0.338 \\
M.Ability & -0.001 & 0.023 & 0.354 & -0.574 & 0.526 \\
ISIS & 0.571 & 1.000 & 0.495 & 0.000 & 1.000 \\
ISIS proximity & 0.500 & 0.500 & 0.501 & 0.000 & 1.000 \\
Firm Size & 9.615 & 9.708 & 0.516 & 8.306 & 11.124 \\
Sales Volatility & 0.103 & 0.074 & 0.120 & 0.008 & 0.685 \\
Cash Flow Volatility & 0.336 & 0.081 & 1.145 & 0.005 & 1.076 \\
Operating Cycle & 109.987 & 107.34 & 58.097 & 22.764 & 296.897 \\
Big Auditor & 0.073 & 0.000 & 0.261 & 0.000 & 1.000 \\
Loss & 0.408 & 0.000 & 0.492 & 0.000 & 1.000 \\
Sales Growth & 0.238 & 0.021 & 0.875 & -0.795 & 19.795 \\
Return on Assets & 0.014 & 0.056 & 0.157 & -0.267 & 0.413 \\
\hline
\end{tabular}

Notes: This table presents descriptive statistics for the main research variables. 
Table 2: Managerial ability and earnings quality

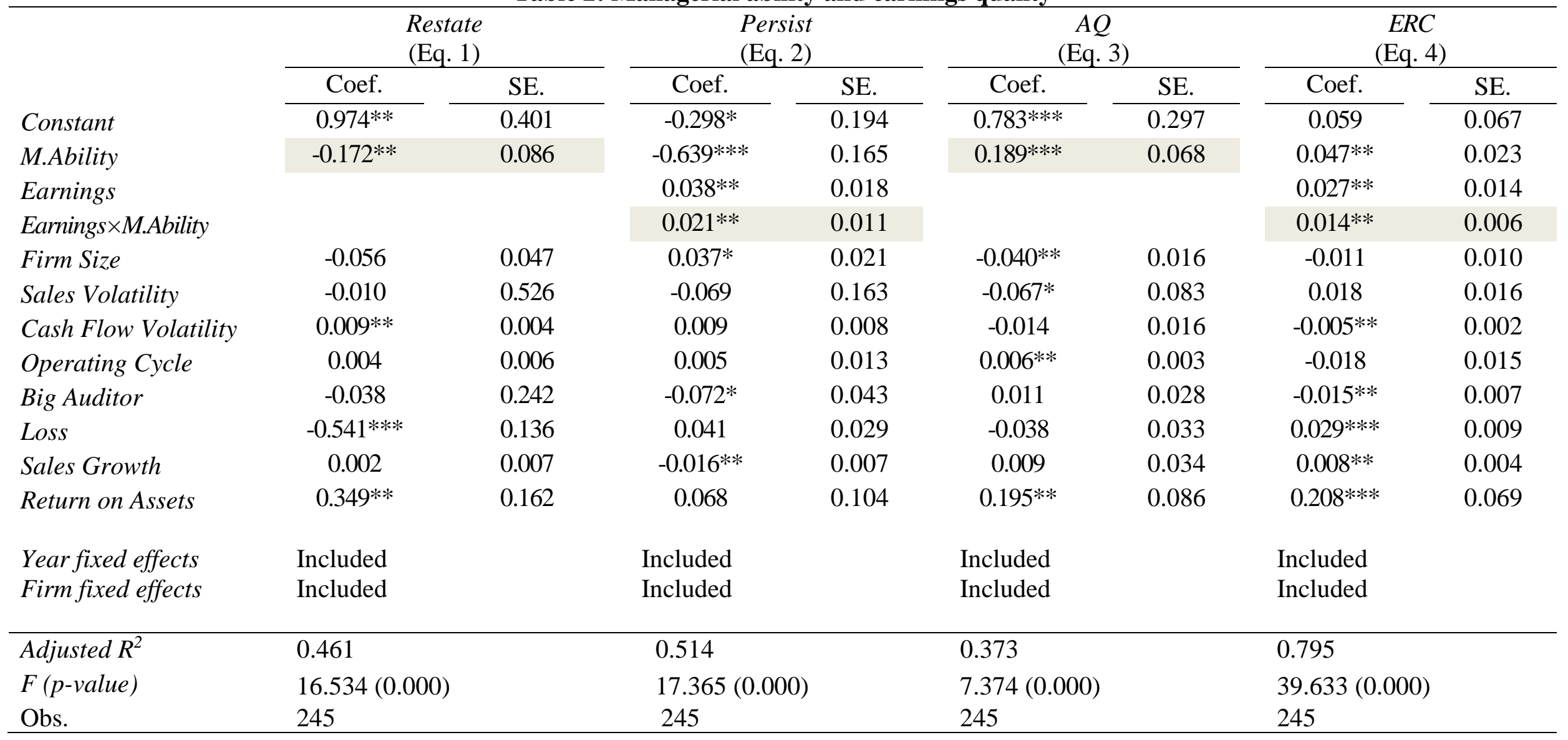

Notes: This table shows the association between managerial ability and four earnings quality metrics. $*, * *, * *$ Significant at $10 \%, 5 \%$ and $1 \%$, respectively. Standard errors are clustered by firm. 
Table 3: Impact of ISIS

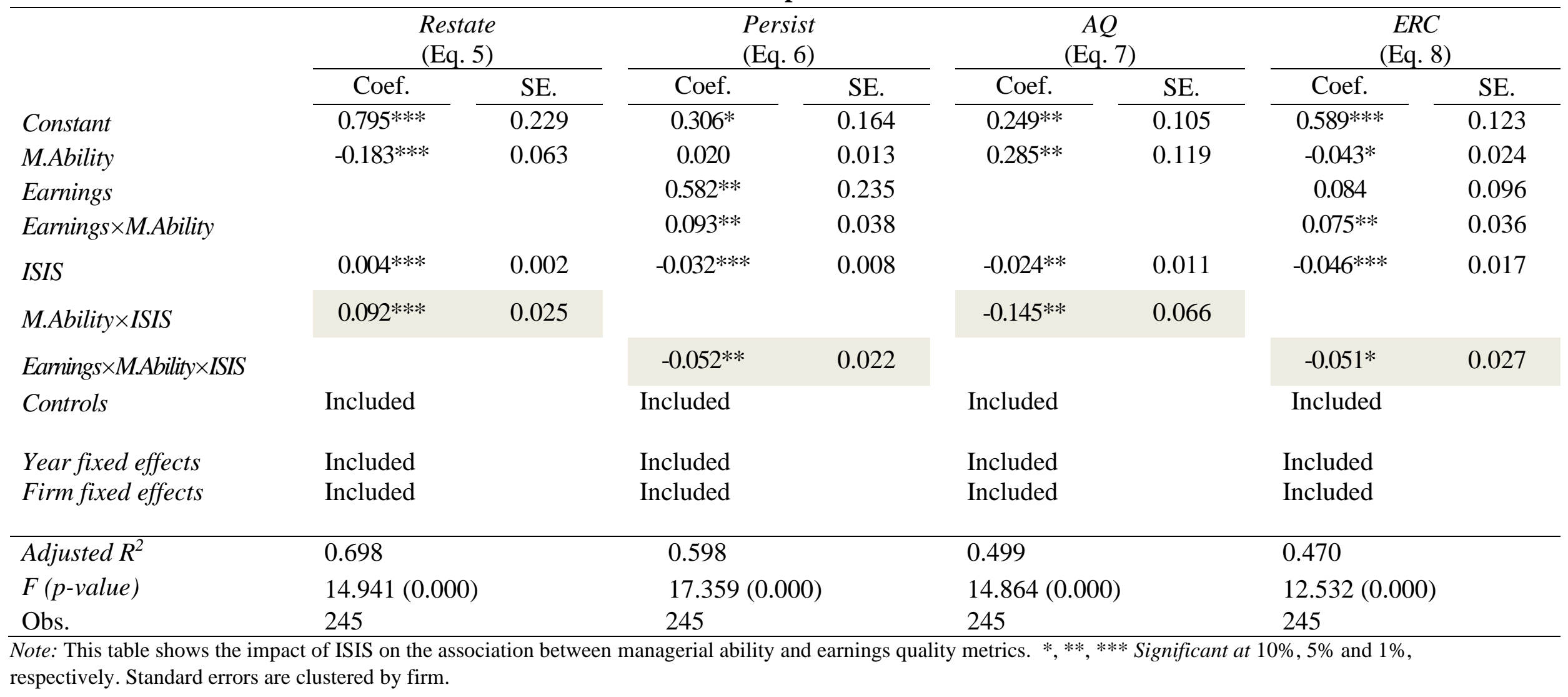


Figure 2: Effect size of ISIS

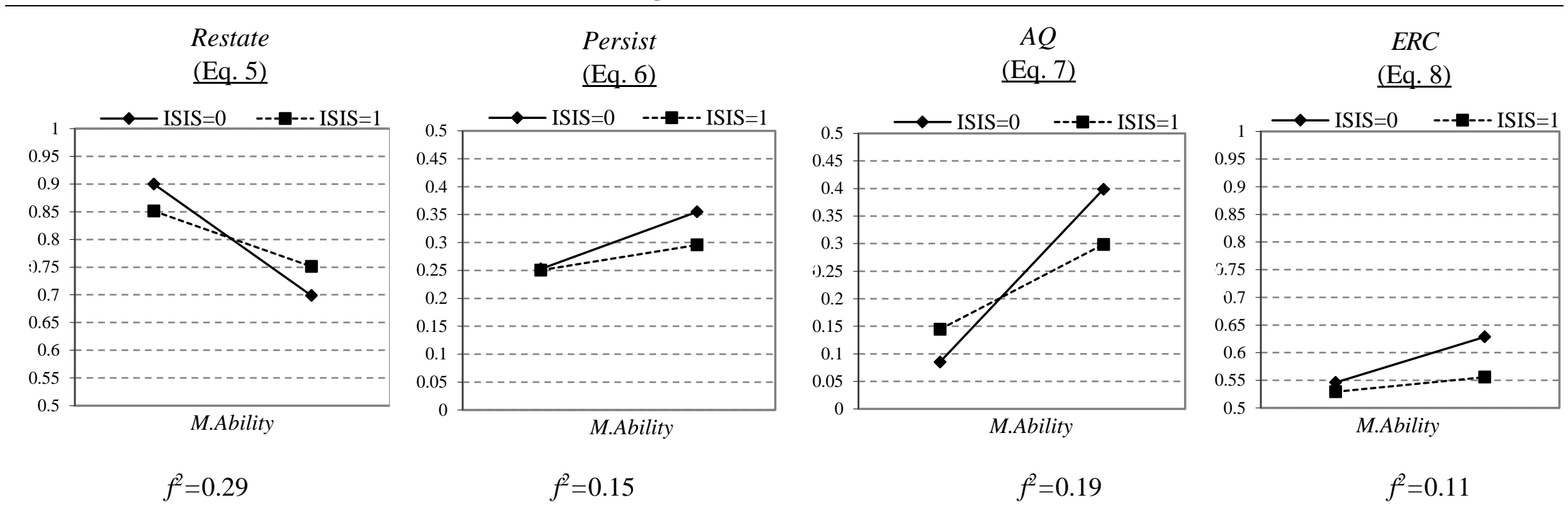

Notes: This figure displays the strength of ISIS moderating effect in the relationship between managerial ability and earnings quality metrics. $f^{2}$ is the ratio of variance explained by the interaction term alone to the unexplained variance in the Equations 5 to 8 . 
Table 4: Impact of proximity to ISIS territories

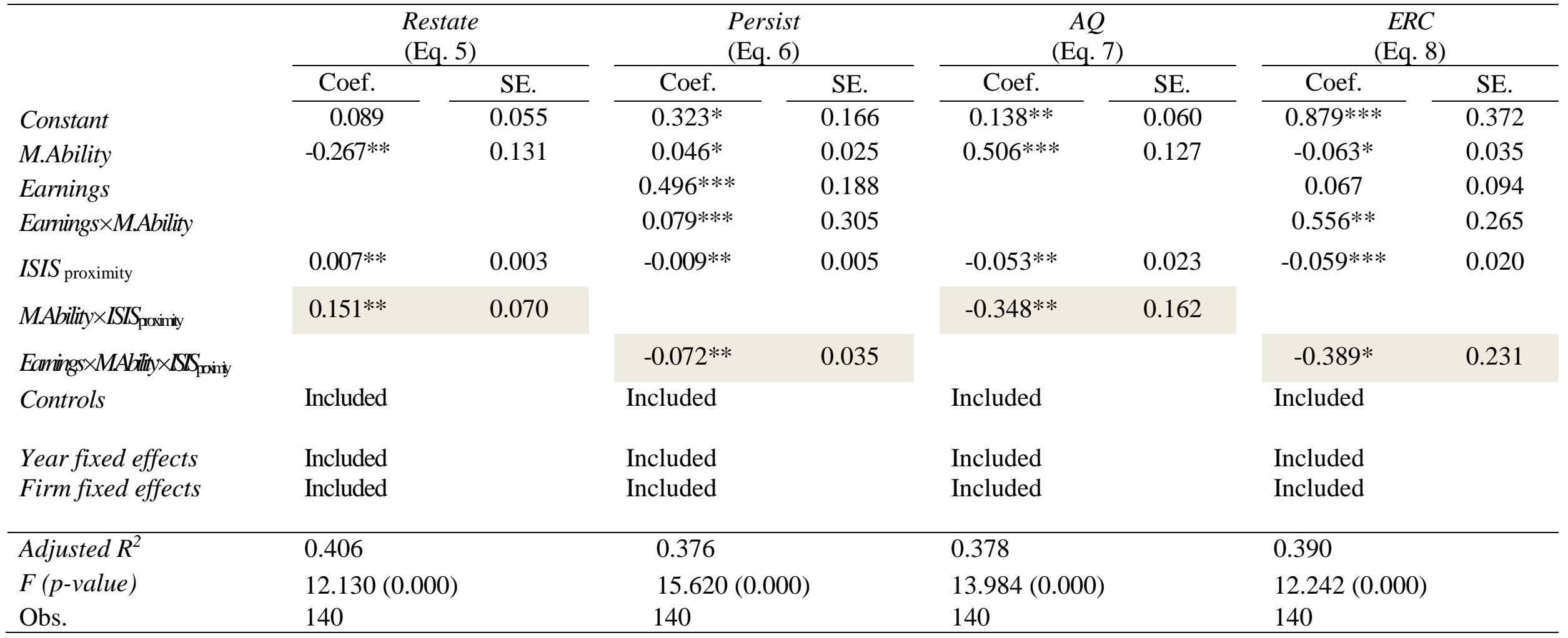

Notes: This table shows the impact of geographical proximity to ISIS on the association between managerial ability and earnings quality metrics. *, **,*** Significant at $10 \%, 5 \%$ and $1 \%$, respectively. Standard errors are clustered by firm. 
Table 5: Alternative measure of managerial ability

Panel A: Managerial ability and earnings quality

\begin{tabular}{|c|c|c|c|c|c|c|c|c|}
\hline \multirow{4}{*}{$\begin{array}{l}\text { Constant } \\
\text { M.Ability } \text { comp }\end{array}$} & \multicolumn{2}{|c|}{$\begin{array}{l}\text { Restate } \\
\text { (Eq. 1) }\end{array}$} & \multicolumn{2}{|c|}{$\begin{array}{l}\text { Persist } \\
\text { (Eq. 2) }\end{array}$} & \multicolumn{2}{|c|}{$\begin{array}{c}A Q \\
\text { (Eq. 3) }\end{array}$} & \multicolumn{2}{|c|}{$\begin{array}{c}E R C \\
\text { (Eq. 4) }\end{array}$} \\
\hline & Coef. & SE. & Coef. & SE. & Coef. & SE. & Coef. & SE. \\
\hline & \multicolumn{2}{|l|}{ Included } & \multicolumn{2}{|l|}{ Included } & \multicolumn{2}{|l|}{ Included } & \multicolumn{2}{|l|}{ Included } \\
\hline & $-0.033 * *$ & 0.016 & $-0.051 * *$ & 0.024 & $0.074 * * *$ & 0.020 & $0.021 *$ & 0.012 \\
\hline \multirow{2}{*}{\multicolumn{3}{|c|}{$\begin{array}{l}\text { Earnings } \\
\text { Earnings } \times \text { M.Ability }_{\text {comp }}\end{array}$}} & $0.037^{*}$ & 0.019 & & & $-0.033^{*}$ & 0.019 \\
\hline & & & $0.021 * *$ & 0.010 & & & $0.018 *$ & 0.010 \\
\hline Controls & \multicolumn{2}{|l|}{ Included } & \multicolumn{2}{|l|}{ Included } & \multicolumn{2}{|l|}{ Included } & \multicolumn{2}{|l|}{ Included } \\
\hline $\begin{array}{l}\text { Year fixed effects } \\
\text { Firm fixed effects }\end{array}$ & \multicolumn{2}{|l|}{$\begin{array}{l}\text { Included } \\
\text { Included }\end{array}$} & \multicolumn{2}{|l|}{$\begin{array}{l}\text { Included } \\
\text { Included }\end{array}$} & \multicolumn{2}{|l|}{$\begin{array}{l}\text { Included } \\
\text { Included }\end{array}$} & \multicolumn{2}{|l|}{$\begin{array}{l}\text { Included } \\
\text { Included }\end{array}$} \\
\hline Adjusted $R^{2}$ & \multicolumn{2}{|l|}{0.418} & \multicolumn{2}{|l|}{0.462} & \multicolumn{2}{|l|}{0.410} & \multicolumn{2}{|l|}{0.598} \\
\hline$F(p$-value $)$ & \multicolumn{2}{|c|}{$13.651(0.000)$} & \multicolumn{2}{|c|}{$15.653(0.000)$} & \multicolumn{2}{|c|}{$7.764(0.000)$} & \multicolumn{2}{|c|}{$33.431(0.000)$} \\
\hline Obs. & \multicolumn{2}{|l|}{168} & \multicolumn{2}{|l|}{168} & \multicolumn{2}{|l|}{168} & \multicolumn{2}{|l|}{168} \\
\hline
\end{tabular}


Panel B: Impact of ISIS

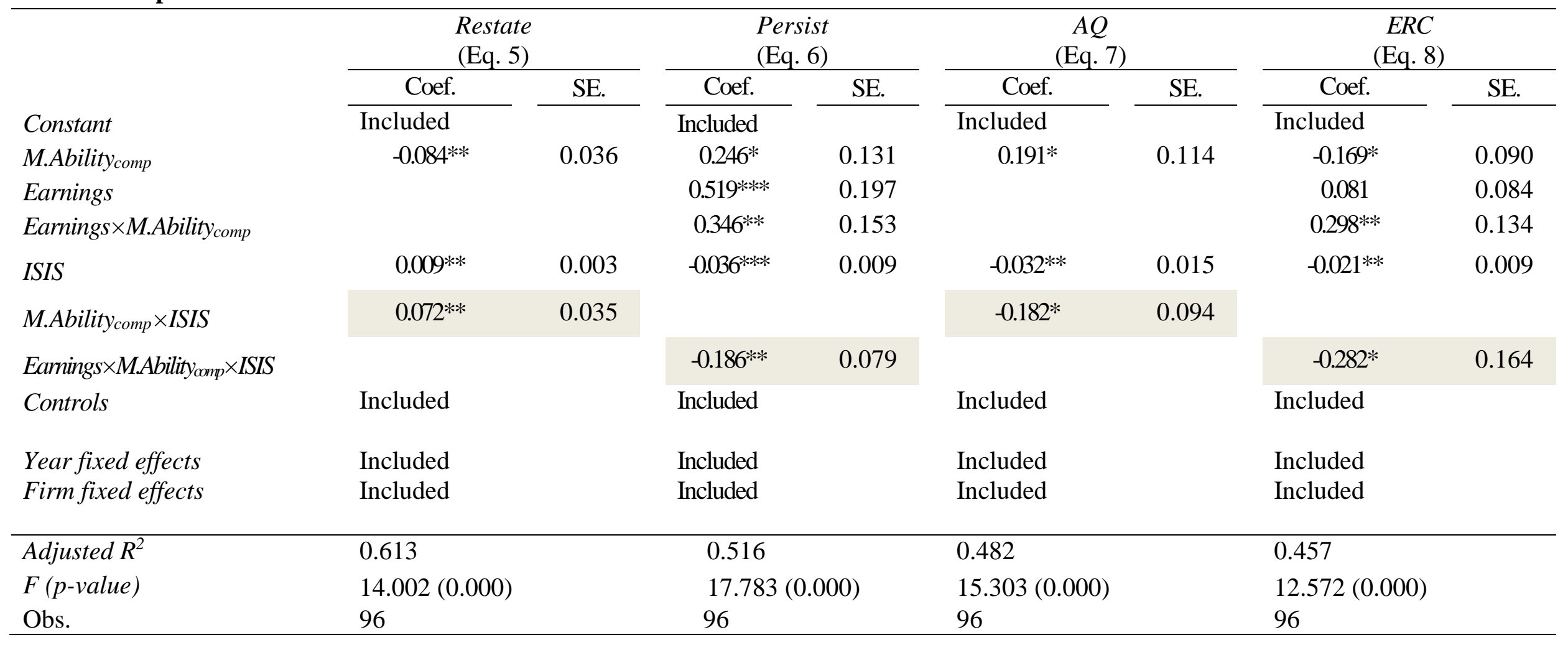


Panel C: Impact of proximity to ISIS territories

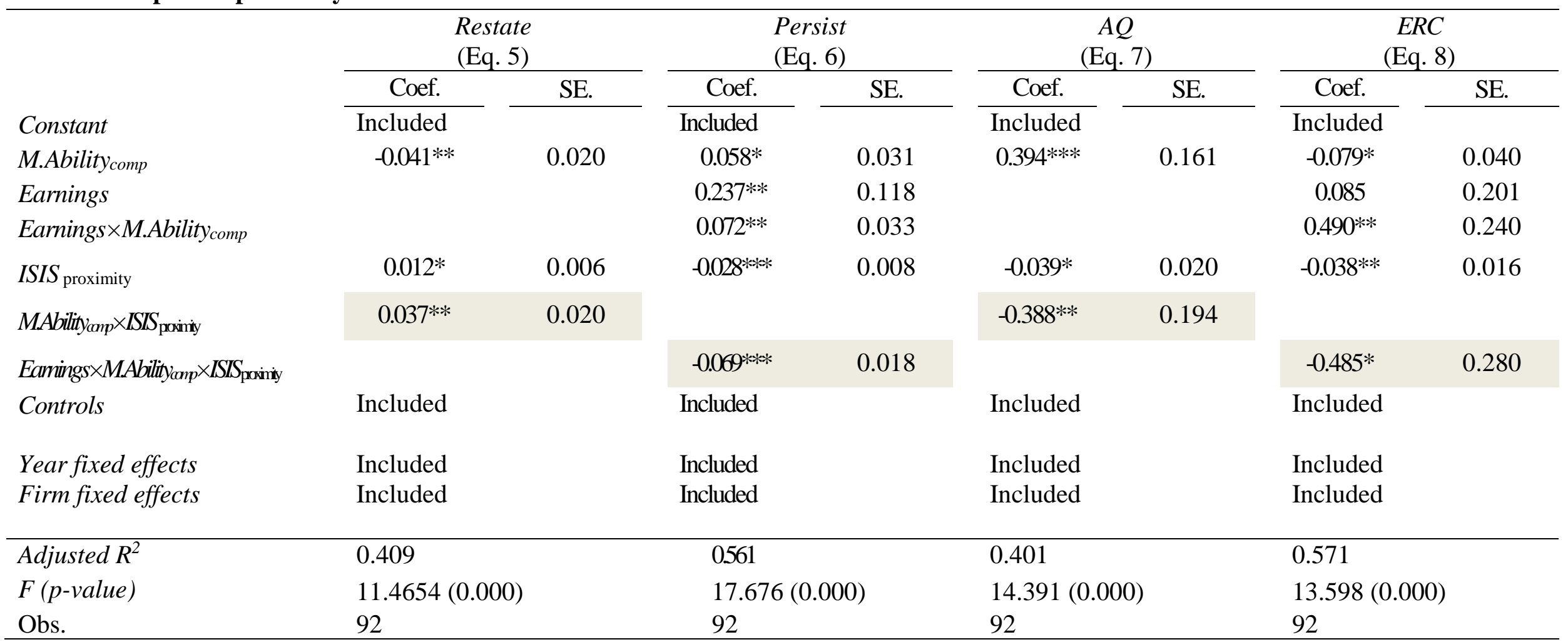

Notes: This table shows the results of re-examining the research hypotheses using the composite measure of managerial ability. *,**,*** Significant at $10 \%, 5 \%$ and $1 \%$, respectively. Standard errors are clustered by firm. 
Table 6: Propensity score matching

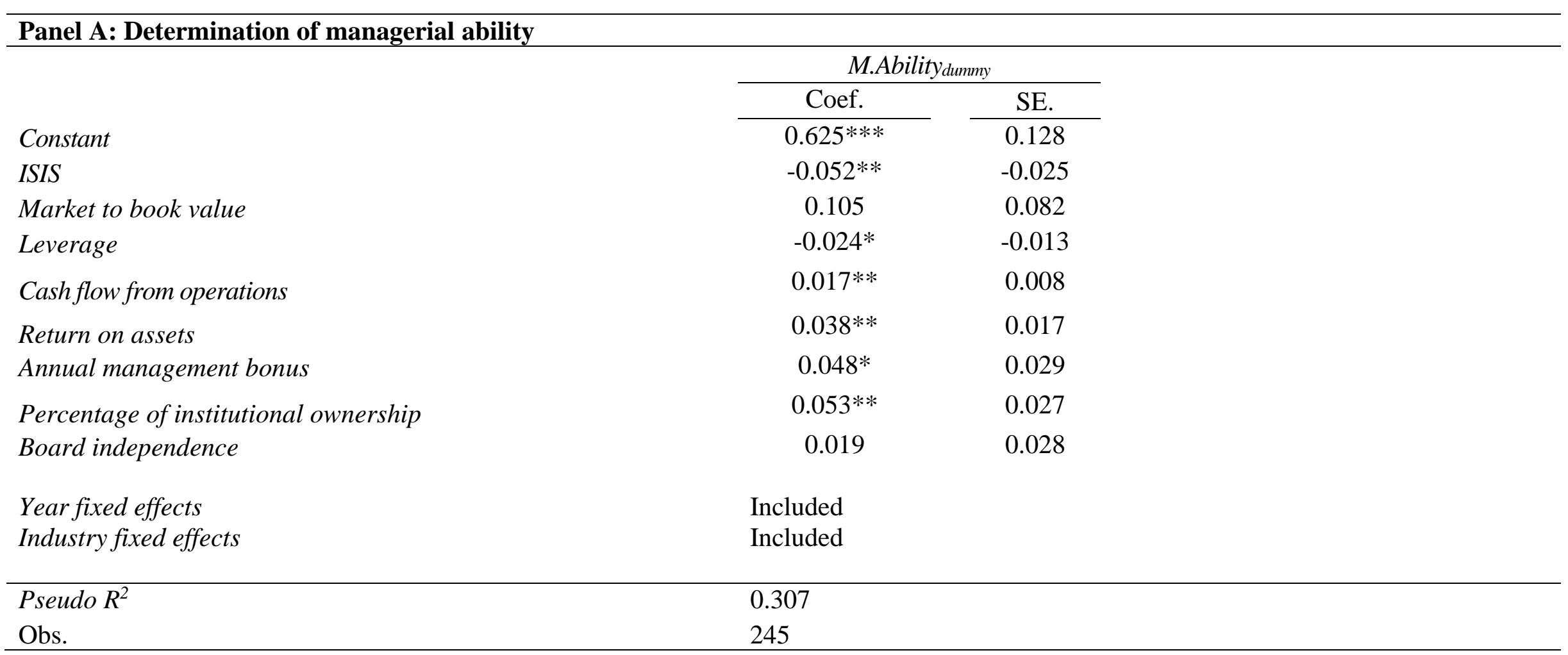


Panel B: Association between managerial ability and earnings quality using a matched sample

\begin{tabular}{|c|c|c|c|c|c|c|c|c|}
\hline \multirow[b]{3}{*}{ Constant } & \multicolumn{2}{|c|}{$\begin{array}{l}\text { Restate } \\
\text { (Eq. } 5)\end{array}$} & \multicolumn{2}{|c|}{$\begin{array}{l}\text { Persist } \\
\text { (Eq. 6) }\end{array}$} & \multicolumn{2}{|c|}{$\begin{array}{c}A Q \\
(\mathrm{Eq} .7)\end{array}$} & \multicolumn{2}{|c|}{$\begin{array}{c}E R C \\
(\mathrm{Eq} .8)\end{array}$} \\
\hline & Coef. & SE. & Coef. & SE. & Coef. & SE. & Coef. & SE. \\
\hline & \multicolumn{2}{|l|}{ Included } & \multicolumn{2}{|l|}{ Included } & \multicolumn{2}{|l|}{ Included } & \multicolumn{2}{|l|}{ Included } \\
\hline M.Ability & $-0.196 * *$ & 0.094 & $-0.579 * *$ & 0.245 & $0.284 * * *$ & 0.079 & $0.032 * *$ & 0.014 \\
\hline Earnings & & & $0.029 *$ & 0.015 & & & $-0.035^{*}$ & 0.019 \\
\hline Earnings $\times$ M.Ability & & & $0.011 *$ & 0.007 & & & $0.029 * *$ & 0.011 \\
\hline Controls & \multicolumn{2}{|l|}{ Included } & \multicolumn{2}{|l|}{ Included } & \multicolumn{2}{|l|}{ Included } & \multicolumn{2}{|l|}{ Included } \\
\hline $\begin{array}{l}\text { Year fixed effects } \\
\text { Firm fixed effects }\end{array}$ & \multicolumn{2}{|l|}{$\begin{array}{l}\text { Included } \\
\text { Included }\end{array}$} & \multicolumn{2}{|l|}{$\begin{array}{l}\text { Included } \\
\text { Included }\end{array}$} & \multicolumn{2}{|l|}{$\begin{array}{l}\text { Included } \\
\text { Included }\end{array}$} & \multicolumn{2}{|l|}{$\begin{array}{l}\text { Included } \\
\text { Included }\end{array}$} \\
\hline Adjusted $R^{2}$ & \multicolumn{2}{|l|}{0.563} & \multicolumn{2}{|l|}{0.673} & \multicolumn{2}{|l|}{0.397} & \multicolumn{2}{|l|}{0.328} \\
\hline$F(p$-value $)$ & \multicolumn{2}{|c|}{$15.274(0.000)$} & \multicolumn{2}{|c|}{$17.874(0.000)$} & \multicolumn{2}{|c|}{$12.099(0.000)$} & \multicolumn{2}{|c|}{$11.642(0.000)$} \\
\hline Obs. & \multicolumn{2}{|l|}{164} & \multicolumn{2}{|l|}{164} & \multicolumn{2}{|c|}{164} & \multicolumn{2}{|l|}{164} \\
\hline
\end{tabular}

Notes: This table shows the impact of ISIS on the association between managerial ability and earnings quality metrics using a PSM analysis. *, **, *** Significant at $10 \%$, $5 \%$ and $1 \%$, respectively. Standard errors are clustered by firm. 
Table 7: Difference-in-differences analysis

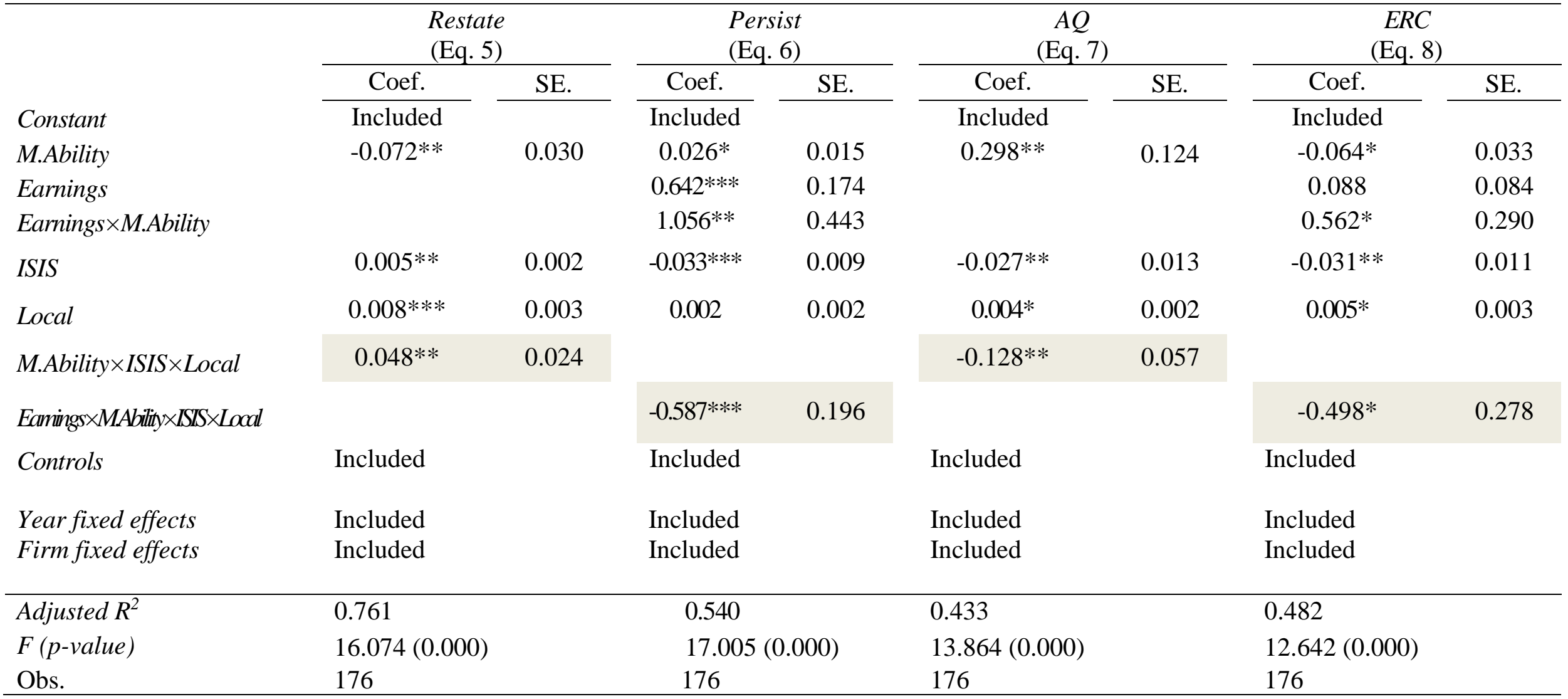

Notes: This table shows the impact of ISIS on the association between managerial ability and earnings quality metrics using a difference-in-differences analysis. *,**,*** Significant at 10\%, 5\% and 1\%, respectively. Standard errors are clustered by firm. 
Table 8: How macroeconomic variables affect research results

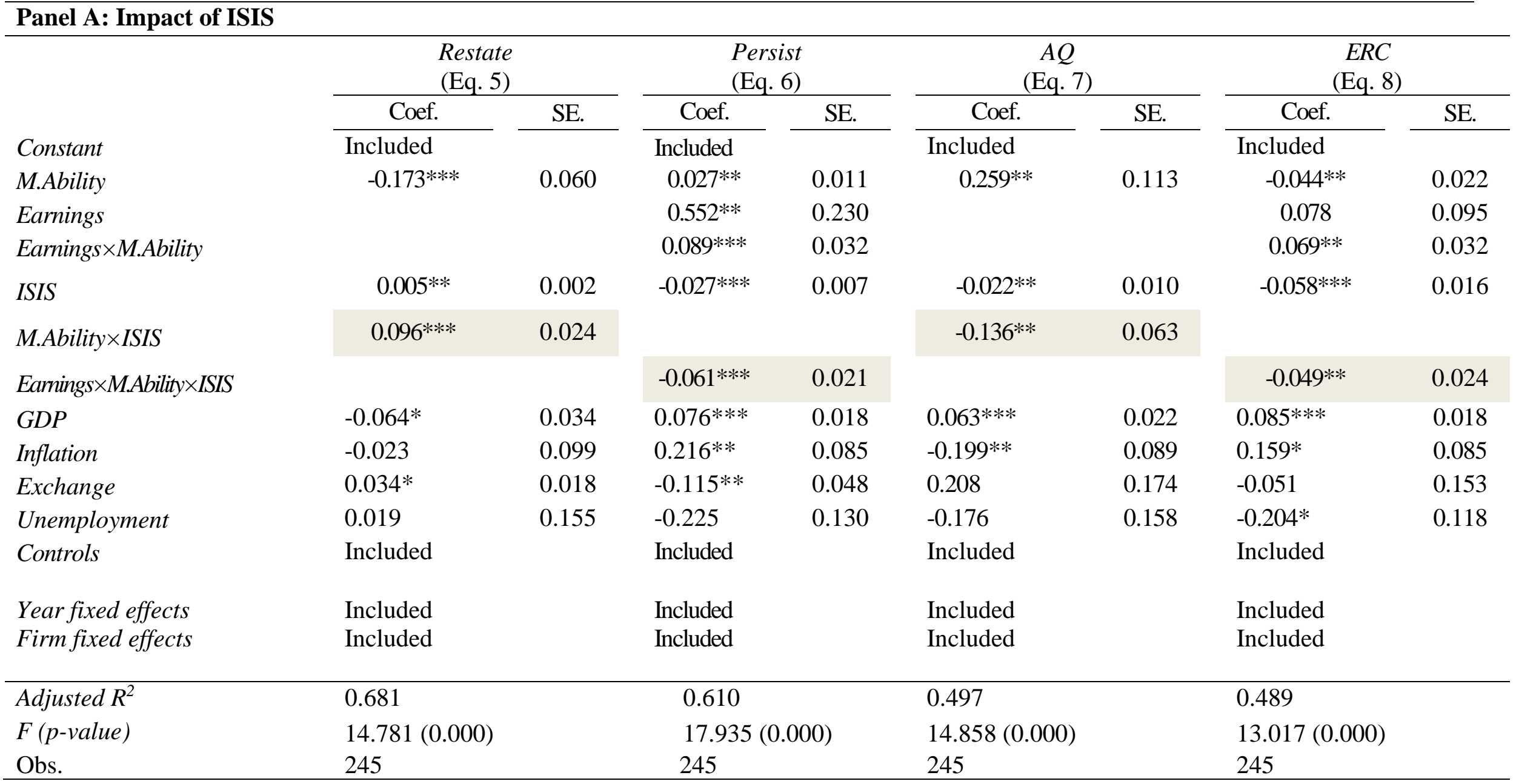


Panel B: Impact of proximity to ISIS territories

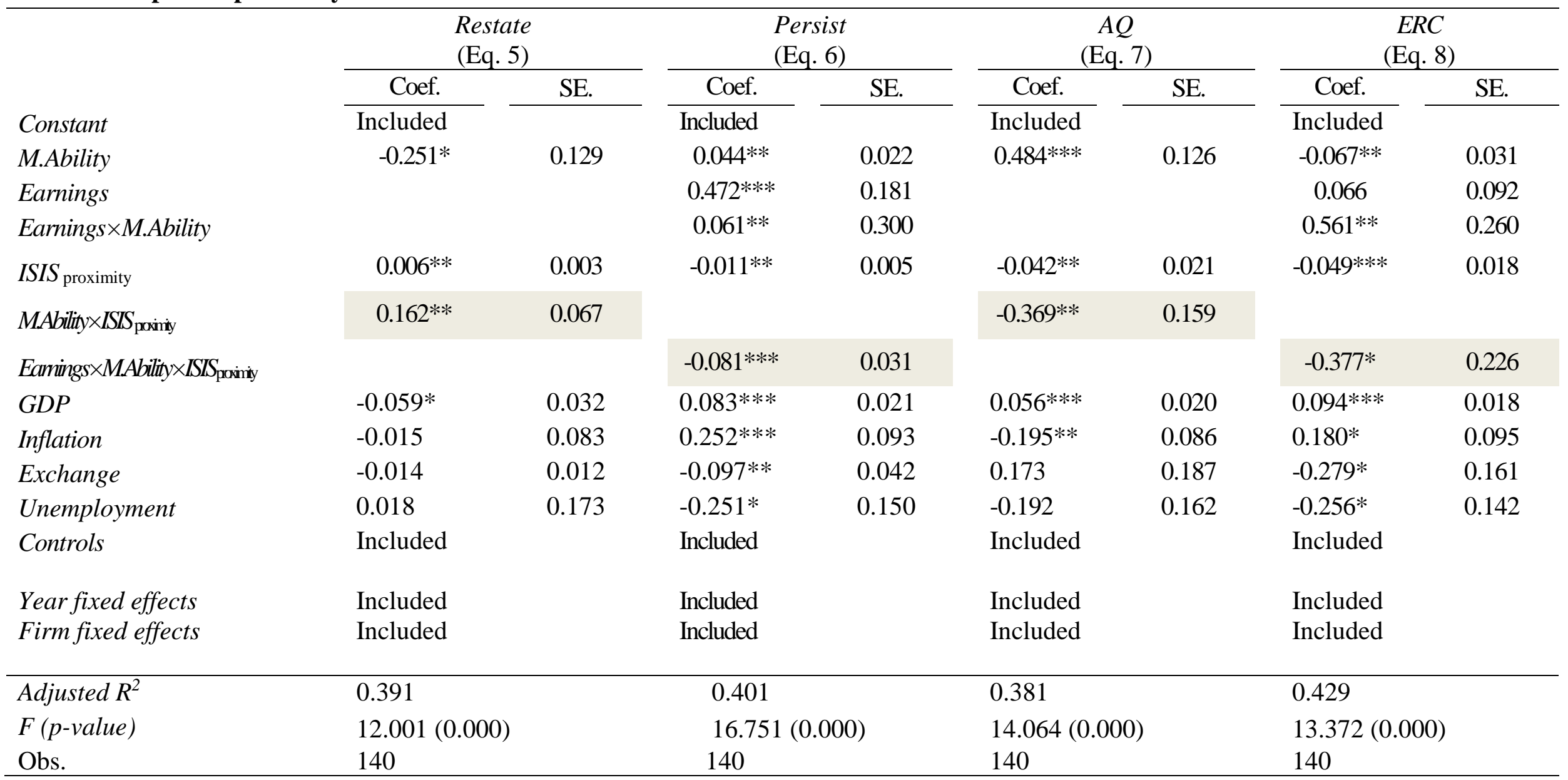

Notes: This table shows the results of re-examining research hypotheses after the inclusion of key macroeconomic variables in empirical models. * $* *, * * *$ Significant at $10 \%, 5 \%$ and $1 \%$, respectively. Standard errors are clustered by firm. 